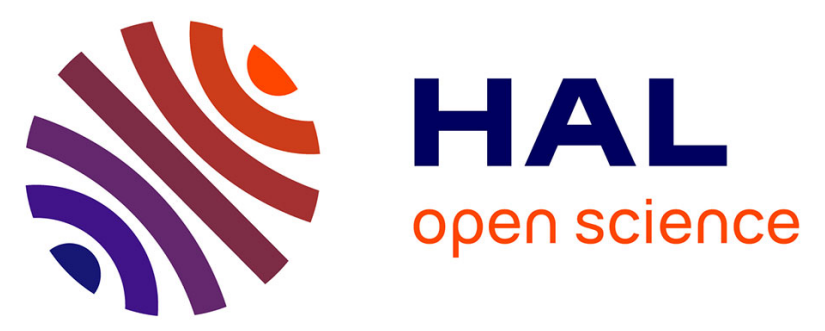

\title{
Variability in particle attenuation and chlorophyll fluorescence in the tropical Pacific: Scales, patterns, and biogeochemical implications
}

Hervé Claustre, A Morel, M Babin, C Cailliau, D Marie, Jc Marty, D Tailliez, D Vaulot

\section{To cite this version:}

Hervé Claustre, A Morel, M Babin, C Cailliau, D Marie, et al.. Variability in particle attenuation and chlorophyll fluorescence in the tropical Pacific: Scales, patterns, and biogeochemical implications. Journal of Geophysical Research. Oceans, 1999, 104 (C2), pp.3401-3422. 10.1029/98JC01334 . hal03284914

\section{HAL Id: hal-03284914 \\ https://hal.science/hal-03284914}

Submitted on 14 Jul 2021

HAL is a multi-disciplinary open access archive for the deposit and dissemination of scientific research documents, whether they are published or not. The documents may come from teaching and research institutions in France or abroad, or from public or private research centers.
L'archive ouverte pluridisciplinaire HAL, est destinée au dépôt et à la diffusion de documents scientifiques de niveau recherche, publiés ou non, émanant des établissements d'enseignement et de recherche français ou étrangers, des laboratoires publics ou privés.

$$
\text { Copyright }
$$




\title{
Variability in particle attenuation and chlorophyll fluorescence in the tropical Pacific: Scales, patterns, and biogeochemical implications
}

\author{
Hervé Claustre, ${ }^{1}$ André Morel, ${ }^{1}$ Marcel Babin, ${ }^{1}$ Caroline Cailliau, ${ }^{1}$ Dominique \\ Marie, ${ }^{2}$ Jean-Claude Marty, ${ }^{1}$ Dominique Tailliez, ${ }^{1}$ and Daniel Vaulot ${ }^{2}$
}

\begin{abstract}
The variability in particle attenuation $\left(c_{\mathrm{p}}\right)$ and in chlorophyll in situ fluorescence $\left(F_{\text {is }}\right)$ was examined in November 1994 along $150^{\circ} \mathrm{W}$ in the Pacific Ocean. Two main sources of variation in $c_{\mathrm{p}}$ and $F_{\text {is }}$ profiles are identified by analyzing data from a $16^{\circ} \mathrm{S}-1^{\circ} \mathrm{N}$ transect, and from two 5 day stations $\left(5^{\circ} \mathrm{S}\right.$ and $\left.16^{\circ} \mathrm{S}\right)$. The first source reflects changes in the trophic status resulting from prevailing hydrodynamical regimes at large scales. By using flow cytometric data and some assumptions about the size distribution of the different biological stocks, a decomposition of $c_{\mathrm{p}}$ into its vegetal $\left(c_{\mathrm{veg}}\right)$ and nonvegetal $\left(c_{\text {nveg }}\right.$ ) components is attempted. Within the euphotic layer, $c_{\text {veg }}$ accounts for $43 \%$ of the total $c_{\mathrm{p}}$ signal at the equator and for only $20 \%$ in the South Pacific gyre. The nonvegetal component is then subdivided into heterotrophic organisms and detritus contributions. The detrital material is an important contributor with $43 \%$ of $c_{\mathrm{p}}$ at $5^{\circ} \mathrm{S}$ and $55 \%$ at $16^{\circ} \mathrm{S}$. A further decomposition of $F_{\text {is }}$ and $c_{\text {veg }}$ into the three dominant phytoplanktonic groups (Prochlorococcus, Synechococcus, and picoeucaryotes) confirms that picoeucaryotes are important contributors of the vegetal biomass, especially within and below the deep chlorophyll maximum (DCM) ( $>50 \%$ of the algal stock) at $16^{\circ} \mathrm{S}$. The second, and essentially local, source of variation is related to specific rhythms in biological and physiological processes. The prominent signals detected during the time series occur at the daily scale: besides the pronounced fluorescence depression at noon in upper layers, particle attenuation in all the layers examined and fluorescence in the DCM display conspicuous daily oscillations. They result from the balance between daytime accumulation and night removal of particles, of algal cells in particular. Finally, the estimation of $c_{\mathrm{p}}$-based growth rates points out the surprisingly rapid turnover time of the whole particulate matter stock in oligotrophic waters $\left(16^{\circ} \mathrm{S}\right)$, not only in the euphotic zone $\left(0.63 \mathrm{~d}^{-1}\right)$ but also within the dimly lit layers of the DCM $\left(0.36 \mathrm{~d}^{-1}\right)$. The corresponding growth rate at $5^{\circ} \mathrm{S}$, within a quasi-mesotrophic regime, is $0.47 \mathrm{~d}^{-1}$ within the euphotic zone.
\end{abstract}

\section{Introduction}

Reconciliating different determinations of carbon flux distribution on a global scale from extrapolation of various measurements performed at different spatiotemporal scales has proven to be a very difficult task [Platt and Sathyendranath, 1988]. The assessment of biological and chemical stocks, as well as the analysis of specific processes govern-

\footnotetext{
${ }^{1}$ Observatoire Océanologique de Villefranche, Laboratoire de Physique et Chimie Marines, Université Pierre et Marie Curie and Centre National de la Recherche Scientifique / Institut National des Sciences de l'Univers, Villefranche-sur-mer, France.

${ }^{2}$ Station Biologique de Roscoff, Université Pierre et Marie Curie and Centre National de la Recherche Scientifique / Institut National des Sciences de l'Univers, Roscoff, France.
}

Copyright 1999 by the American Geophysical Union.

Paper number 98JC01334.

0148-0227/99/98JC-01334\$09.00 ing the exchanges and fluxes between these stocks, are, in many circumstances, only representative of the spatial and temporal context of their acquisition. As such, they are not amenable to safe generalization. Prompted by global studies there is, however, a recurrent temptation (actually a need) to extrapolate episodic and sporadic information for longer and wider scales, with the obvious risks in doing so. When using inadequate sampling strategies, either important events may be easily missed, or, if captured, they can bias what will be further considered as a representative average.

Satellites are able to encompass the global scale in a repetitive manner; yet they fail in resolving small scales, like depth-dependent variability or circadian cycles. Observations from ship, in principle, allow small-scale events and vertically resolved structures to be studied; they, nevertheless, remain limited in space and time coverage. The implementation of profilers providing continuous (or highfrequency) measurements represents a partial solution for filling the gap between spaceborne and shipborne observa- 
tional capacities. Profilers can operate quickly, they can be towed, and similar sensors can be included in moored instrumentation deployment [Abbott et al., 1990; Strass, 1990; Dickey et al., 1991; Stramska and Dickey, 1992; Marra, 1997]

Generally interfaced with conductivity-temperature-depth (CTD) devices, two types of profilers are increasingly involved in biogeochemical studies, namely, in situ fluorometers and beam transmissometers. The first sensor measures the stimulated fluorescence emission by chlorophyll $a$ (chl $a$ ), thereafter used as a proxy of the chl $a$ concentration and as a rough descriptor of algal biomass [Lorenzen, 1966]. The second one measures the attenuation coefficient, the variations of which are essentially determined by particle scattering, so that it can be regarded as a descriptor of the particulate matter load [e.g. Gardner et al., 1990]. It must be stressed that both measurements deal only with bulk properties, to the extent that important qualitative aspects of the particulate material nature are not directly accessible. The distribution of these particles between the algal and nonalgal compartments, as well as the species composition inside the algal population, remain undetected by such techniques as long as they are not complemented by other experimental approaches, such as flow cytometry, high-performance liquid-chromatography (HPLC) pigment determination, optical measurements, and so forth.

As for the signals simultaneously delivered by the two sensors, two main sources of variations can be identified. Inducing the strongest signal amplitudes and marked geographical gradients, the first source is simply related to the trophic regime as a response to the main hydrographic features and the resulting nutrient availability; at this scale, rather concomitant trends occur for both fluorescence and attenuation. The second source of variations, superimposed on the general trend, represents a local response of the various compartments to high-frequency fluctuations in the physical field; they are either episodic (wind events or cloudiness, for instance) or periodic (internal waves, irradiation daily cycle, or nocturnal convection). Such variations, detected by fluorometry and transmissometry, are rather weak (compared to those related to trophic state); they are closely linked to the physiological cycles of algae (division rate and metabolism) or to their predators (grazing and vertical migrations). Time series at high-frequency with vertically detailed observations at fixed stations allowed these intermingled processes to be documented.

One of the major goals of the general Joint Global Ocean Flux Study (JGOFS) in the equatorial Pacific [Murray et al., 1994] was to determine how much of the variability in biological biomasses and productivity originates from changes in physical forcing as opposed to variations in the biological process rates themselves. The considerations developed above as well as the specific aims of the present work are along this general line. They motivated the investigations carried out in the frame of the French JGOFS program in the Pacific. In particular, this program included a detailed study of the sources of variability of chlorophyll fluorescence and particle attenuation as well as the analysis of the relation- ships between, and the complementary nature of, both signals.

The first part of this paper is focused on the influence of the trophic status on the particulate matter as detected through fluorescence and attenuation measurements. Data from a transect encompassing various hydrological conditions along $150^{\circ} \mathrm{W}\left(16^{\circ} \mathrm{S}-1^{\circ} \mathrm{N}\right)$ are analyzed within a suite of measurements (flow cytometry and HPLC of taxonomic pigments) dealing with the particle nature and abundance. We evaluate how changes in particle attenuation and fluorescence are driven by the particulate matter composition as a result of the prevailing environmental conditions. Such an approach complements recent studies in the same area, which focused on the various particles contributing to the attenuation coefficient [e.g., Chung et al., 1996; DuRand and Olson, 1996; Chung et al., 1998].

The second part of this paper examines how particle attenuation and fluorescence may vary at local scales as a response to short-term variations in the physical field or in the particle stocks. For this purpose, two sites were selected and investigated during 5 days, one in a quasi-mesotrophic system $\left(5^{\circ} \mathrm{S}\right)$ and the other in an ultraoligotrophic situation $\left(16^{\circ} \mathrm{S}\right)$, both along $150^{\circ} \mathrm{W}$. This second objective extends previous investigations on the diel cycle of particle attenuation [Siegel et al., 1989; DuRand and Olson, 1996; Walsh et al., 1995]; it relates the variations in particle attenuation to those in chl $a$ fluorescence, and also allows the particulate matter turnover rates in these two trophic regimes to be inferred.

\section{Materials and Methods}

\subsection{Profile Acquisition and Reduction of Data}

The first part of the OLIPAC cruise consisted of a southnorth transect from $15^{\circ} \mathrm{S}$ to $1^{\circ} \mathrm{N}$ (Figure 1). Eleven stations were occupied during 14 hours, from 0400 to 1800 LT. During the second part of the cruise, two stations (site "1" at $5^{\circ} \mathrm{S}$ and site "2" at $16^{\circ} \mathrm{S}$ ) were each studied for a 5 day period. The equipment consisted of a Seabird CTD associated with a SeaTech transmissometer $(25 \mathrm{~cm}$ path length and $660 \mathrm{~nm}$ wavelength), a SeaTech fluorometer (excitation at $425 \pm 200$ $\mathrm{nm}$ and emission at $685 \pm 30 \mathrm{~nm}$ ), and a Seabird carrousel, equipped with 24 Niskin sampling bottles (12 L). During the transect, five vertical profiles were generally determined at each station, namely, four between 0400 and $1000 \mathrm{LT}$, and one at $1600 \mathrm{LT}$. At sites 1 and 2, seven to nine profiles were acquired each day at about every third hour.

Beam transmission $T$ (percent) was converted to beam attenuation coefficient $c\left(\mathrm{~m}^{-1}\right)$ using the equation:

$$
c=-(1 / r) \ln (T / 100)
$$

where $r$ is the beam pathlength (meters). The attenuation coefficient $c$ is the sum of individual contributions by seawater $\left(c_{\mathrm{w}}\right)$, colored dissolved organic matter $\left(c_{\mathrm{cdom}}\right)$ and particles $\left(c_{\mathrm{p}}\right)$. The term $c_{\mathrm{cdom}}$ is assumed to be negligible at $660 \mathrm{~nm}$ in oligotrophic waters [Bricaud et al., 1981], while $c_{\mathrm{w}}, 0.364$ $\mathrm{m}^{-1}$ for pure seawater, is constant and factory-calibrated. 


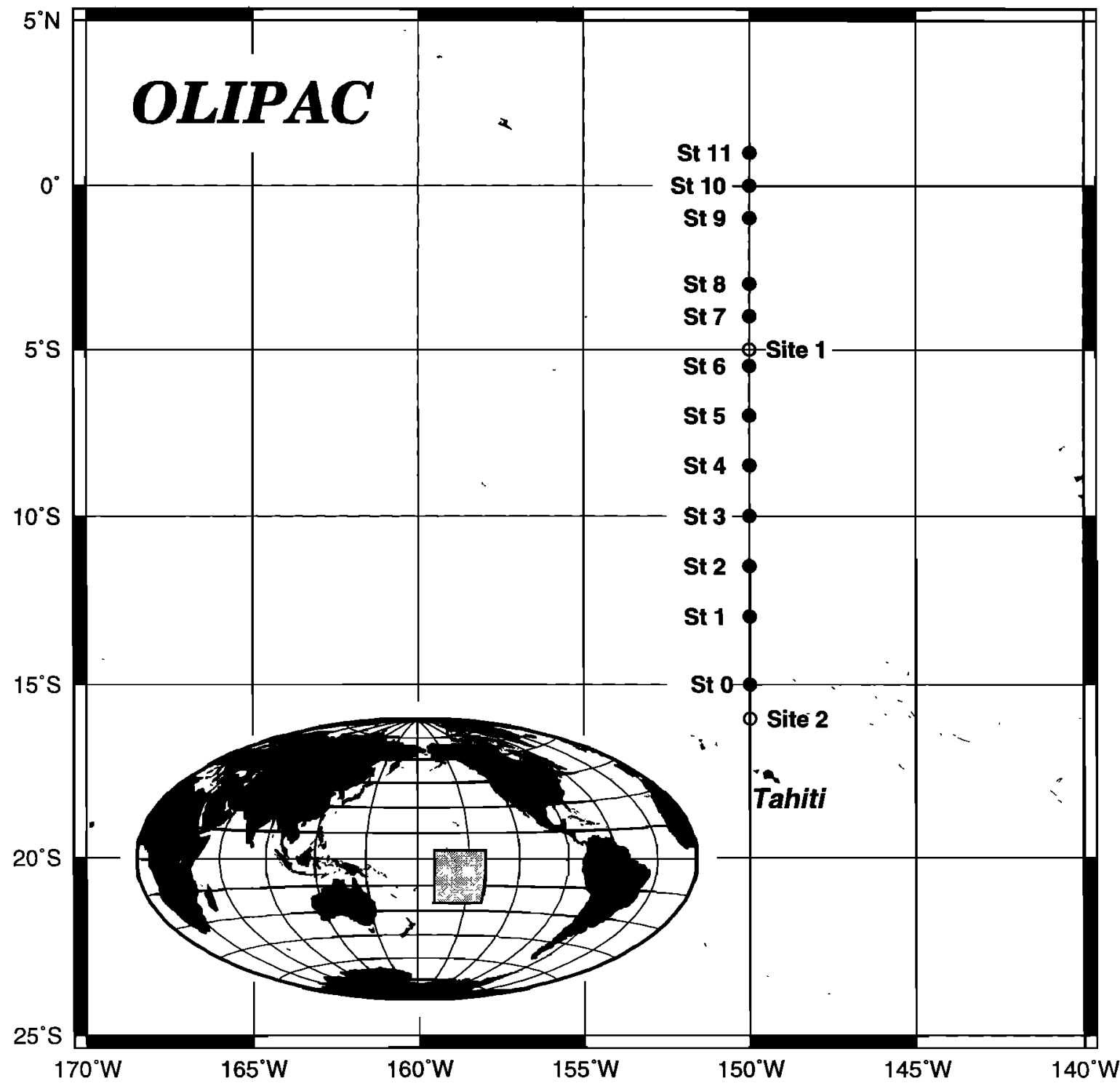

Figure 1. Location of the stations during the OLIPAC cruise along $150^{\circ} \mathrm{W}$ in November 1994 . Site 1 $\left(5^{\circ} \mathrm{S}\right)$ and site $2\left(16^{\circ} \mathrm{S}\right)$ correspond to "long" stations investigated over a 5 day period.

Because the cleanliness of optical windows may change between casts, attenuation profiles in the upper layers were corrected by using the values measured at depths (300 and 400 $\mathrm{m})$, very close to the $c_{\mathrm{w}}$ value above.

In situ fluorescence records $\left(F_{\text {is }}\right)$, in relative units, were shifted upward by $3 \mathrm{dbar}$ to account for the time lag $(3 \mathrm{~s})$ of the fluorometer and for the profiling speed $\left(1 \mathrm{~m} \mathrm{~s}^{-1}\right)$. Density, $F_{\text {is }}$, and $c_{\mathrm{p}}$ values were subsequently binned over $1 \mathrm{~m}$ intervals.

The depth of the mixed layer $(\mathrm{Zm})$ was computed as the depth where the density gradient exceeds $0.01 \mathrm{~kg} \mathrm{~m}^{-4}$. Finally, the euphotic zone depth $(Z e)$, defined as the depth where the photosynthetically available radiation (PAR) is reduced to $1 \%$ of its surface value, was computed from downward irradiance profiles determined by using a LICOR ${ }^{\circledR}(\mathrm{Li}$ $1800 \mathrm{UW}$ ) spectroradiometer.

\subsection{Discrete Data and Other Determinations}

Samples were collected for cytometric measurements, HPLC pigment determination, and carbon analyses. Cell abundance and cellular optical properties (side scatter and chlorophyll fluorescence) of autotrophic picoplankton (Prochlorococcus, Synechococcus, and picoeucaryotes) were determined onboard by flow cytometry, as described by Vaulot and Marie [this issue]. Heterotrophic bacteria were counted later on subsamples fixed with $0.1 \%$ glutaraldehyde and preserved in liquid nitrogen and then stained with $\mathrm{SYBR}^{\circledR} \mathrm{I}$ Green [Marie et al., 1997]. After filtration of $2 \mathrm{~L}$ of seawater onto Whatman GF/F filters, pigment determination and quantification were performed onboard using the HPLC procedure of Vidussi et al. [1996]. For particulate organic carbon (POC) determination, samples $(2.8 \mathrm{~L})$ were fil- 
tered onto GF/F filters previously washed in a soxlet with dichloromethane. This procedure generates blanks as good as combustion at high temperature does with the advantage of preserving the filter porosity. Samples were analyzed using a LECO ${ }^{\circledR} 900$ carbon analyzer with ethylenediaminetetraacetic acid (EDTA) as a standard.

\subsection{Conversion of Optical Signals Into Biogeochemical Variables}

2.3.1. Particle attenuation and POC. The primary sources of variations in $c_{\mathrm{p}}$ are changes in the numerical abundance and the size of particles, while second-order sources are changes in the refractive index and the shape of particles [Gardner et al., 1993]. The size of particles viewed by a transmissometer generally lies in the 0.5-10 $\mu \mathrm{m}$ range, assuming a Junge-type size distribution with an exponent close to -4 [Morel, 1973; Stramski and Kiefer, 1991]. If the particle size distribution, their shape, and refractive index are constant, the $c_{\mathrm{p}}$ variations reflect only particle load changes [Spinrad et al., 1983; Baker and Lavelle, 1984]. These assumptions are necessary to derive particle matter concentrations (PMC) from $c_{\mathrm{p}}$ values [e.g., Siegel et al., 1989; Gardner et al., 1993]. POC can be considered as a proxy of $\mathrm{PMC}$ to the extent that the proportion of organic carbon in $\mathrm{PMC}$ is constant. In the present investigation a significant linear relationship between POC and $c_{\mathrm{p}}$ has been obtained (Figure 2) and leads to a slope of $502 \mathrm{mgC} \mathrm{m}^{-3}$ per $\mathrm{m}^{-1}$ $\left(r^{2}=0.92\right.$ and $\left.n=19\right)$, which can be adopted as a conversion factor allowing $c_{\mathrm{p}}\left(\mathrm{m}^{-1}\right)$ to be transformed into POC equivalent $\left(\mathrm{mgC} \mathrm{m}^{-3}\right)$. By assuming that $40 \%$ of the particulate concentration is POC, Walsh et al. [1995] estimated a conversion factor of 180 and $257 \mathrm{mg} \mathrm{C} \mathrm{m}^{-3}$ per m $\mathrm{m}^{-1}$ for two cruises in the equatorial Pacific, respectively, whereas Cullen et al. [1992] used a value of 255 derived from Siegel et al. [1989] for the north tropical Pacific $\left(33^{\circ} \mathrm{N}, 142^{\circ} \mathrm{W}\right)$. Surprisingly, the present conversion factor is at least twice the previous values. It is, however, the only one directly based on chemical determination instead of an assumption based on the PMC/POC ratio. Moreover, a recent analysis of a large range of POC and attenuation data from several JGOFS cruises [Loisel and Morel, 1998] led to an almost linear relationship $\left(c_{\mathrm{p}}=10^{-3} \mathrm{POC}^{1.17}\right.$ and $\left.r^{2}=0.95\right)$. In the restricted $c_{\mathrm{p}}$ range observed here (i.e., from 0 to $0.10 \mathrm{~m}^{-1}$ ) a linear fit results in a slope of $507\left(r^{2}=0.99\right)$ (see also Figure 2). A conversion value of $500 \mathrm{mg} \mathrm{C} \mathrm{m}^{-3}$ when $c_{\mathrm{p}}=1 \mathrm{~m}^{-1}$ was therefore adopted in what follows. This is equivalent to the adoption of a carbon-specific attenuation cross section, $c_{\mathrm{p}}^{\mathrm{c}}$, of $2 \mathrm{~m}^{2} \mathrm{gC}^{-1}$, a value which also accounts well for other observations made near Hawaii at the HOTS site [Loisel and Morel, 1998, Figure 4].

2.3.2. Fluorescence and chl $a$. In spite of a rather large scatter the relationship between $F_{\text {is }}$ and HPLC-derived chl $a$ (divinyl-chlorophyll $a+$ monovinyl-chlorophyll $a$ ) was significant (Figure 3), and the regression line was used to convert all fluorescence records into chlorophyll $a$ equivalent for the whole transect. In order to account for possible regional differences, separate regressions were performed at $16^{\circ} \mathrm{S}$ and $5^{\circ} \mathrm{S}$, respectively (Figure 3 ). Resulting slope were significantly different (by a factor 1.48). In contrast, there were no significant differences in these slopes when various optical layers were considered in each site (data not shown), which suggests the regional variability is much larger than the vertical one. These site-dependent calibrations will be used when dealing with the 5 day stations at $5^{\circ} \mathrm{S}$ and $16^{\circ} \mathrm{S}$.

\section{Results and Discussion}

\subsection{Analysis of the Meridional Transect}

The density structure along the $150^{\circ} \mathrm{W}$ section and the meridional profile of the geopotential difference (computed between 10 and $1000 \mathrm{dbar}$ ) reveal several distinct regimes related to a complex zonal circulation (Plate 1). In the southern part of the section, between $13^{\circ} \mathrm{S}$ and $9^{\circ} \mathrm{S}$, the prevailing eastward flow, also recorded in the upper layer by acoustic Doppler current profilers (ADCP) [Stoens et al., this issue] is anomalous with respect to the mean pattern described by Wyrtki and Kilonsky [1984]. A net westward motion actually takes place below between 100 and $350 \mathrm{~m}$. Extreme oligotrophic conditions prevail within the zonal band $16^{\circ}$ $14^{\circ} \mathrm{S}$. The upper layers are deprived of nutrients (nitrogen concentration below $10 \mathrm{nM}$ ), phytoplankton is scarce (chl $a$ $<0.10 \mathrm{mg} \mathrm{chl} a \mathrm{~m}^{-3}$ ) and $c_{\mathrm{p}}$ is rather uniformly distributed and weak (0.03-0.04 $\mathrm{m}^{-1}$ ) (Plate 2). A deep chlorophyll maximum (DCM, with chl $a>0.20 \mathrm{mg} \mathrm{chl} a \mathrm{~m}^{-3}$ ) develops well below the $1 \%$ surface PAR level at a fluctuating depth of $\sim 140 \mathrm{~m}$, where nitrogen becomes available $(0.3 \mu \mathrm{M})$. The

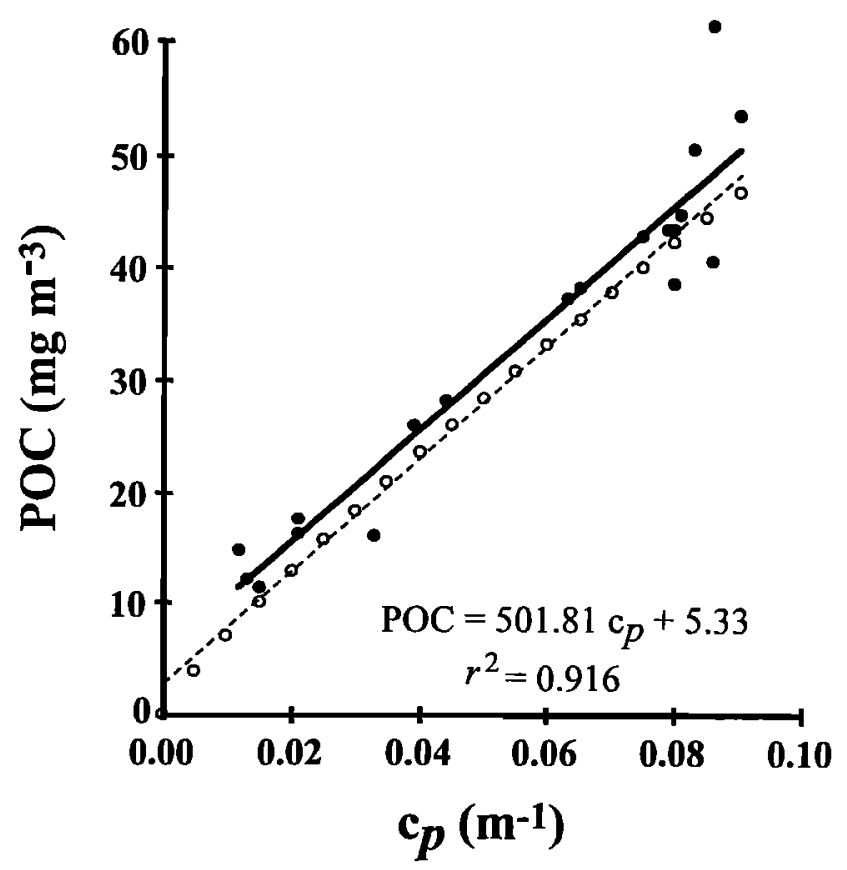

Figure 2. Relationship between particle attenuation $\left(c_{\mathrm{p}}\right)$ and particulate organic carbon (POC). The solid circles, the linear fit (continuous line), and the equation correspond to measurements performed at $5^{\circ} \mathrm{S}, 150^{\circ} \mathrm{W}$. The open circles correspond to values derived from a power law model linking $c_{\mathrm{p}}$ to POC [Loisel and Morel, 1998] fitted to a linear relationship (POC $=506.71 c_{\mathrm{p}}+2.32$ and $r^{2}=0.99$ ) shown as the dashed line. 

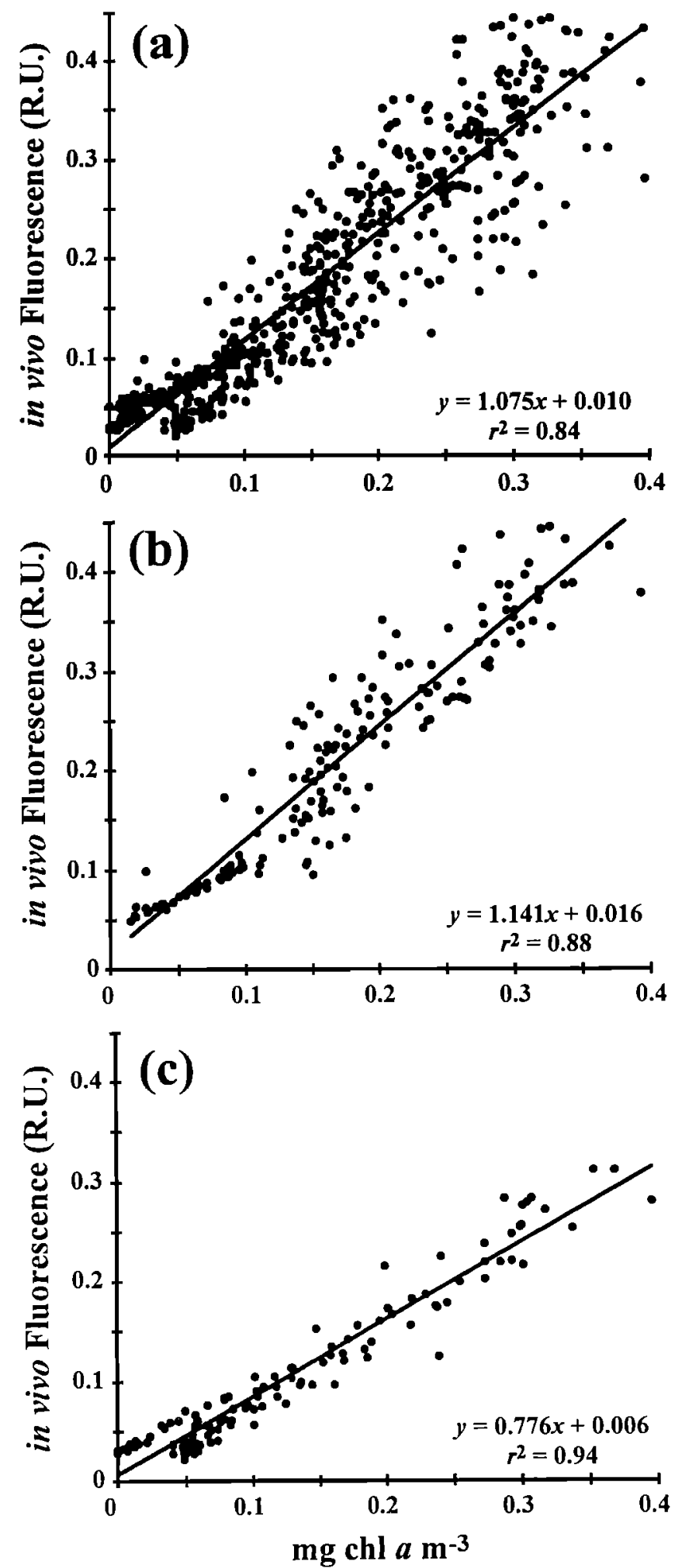

Figure 3. Relationship between in situ fluorescence and chlorophyll $a$ concentration: (a) all measurements performed along the $150^{\circ} \mathrm{W}$ transect (262 data) as well as at $5^{\circ} \mathrm{S}$ (166 data) and $16^{\circ} \mathrm{S}$ (119 data), (b) measurements at $5^{\circ} \mathrm{S}$, and (c) measurements at $16^{\circ} \mathrm{S}$.

mixed layer thickness is $\sim 30 \mathrm{~m}$ or less; below this layer a rather regular density gradient ensures a stable stratification in this area and the maintenance of the layering of various algal assemblages [Vaulot and Marie, this issue].
The extreme oligotrophic character progressively diminishes northward, and the DCM, like the nutricline, rises smoothly. The algal biomass increases in the upper layer as well as in the DCM, while the $c_{\mathrm{p}}$ increase is restricted to the upper layer. The mixed layer extends downward with a maximal thickness of $70 \mathrm{~m}$ at $8^{\circ} 30 \mathrm{~S}$. At this latitude a discontinuity occurs, and the current direction is reversed within the $8^{\circ} 30-7^{\circ} \mathrm{S}$ band. A divergence occurs at $7^{\circ} \mathrm{S}$ between this westward motion $\left(8^{\circ} 30-7^{\circ} \mathrm{S}\right)$ and the eastward motion prevailing between $7^{\circ}$ and $5^{\circ} 30 \mathrm{~S}$. According to the geopotential differences obtained for various isobaric levels (also confirmed by ADCP records), the core of the eastward current is at $\sim 100 \mathrm{~m}$, and the mixed layer depth is shallower $(35 \mathrm{~m})$. Associated with the rising of the pycnoclines, nutrients reach the surface (nitrogen $>2 \mu \mathrm{M}$ ). Between $7^{\circ} \mathrm{S}$ and $3^{\circ} \mathrm{S}$ the algal stock is increased in the upper $(0-50 \mathrm{~m})$ layer with chlorophyll $a$ concentration around $0.20 \mathrm{mg} \mathrm{m}^{-3}$ as well as in the DCM (chl $a>0.35 \mathrm{mg} \mathrm{m}^{-3}$ ), located between 60 and $95 \mathrm{~m}$. This larger algal stock coincides with a noticeable increase in particulate matter within the whole 0-70 $\mathrm{m}$ layer $\left(c_{\mathrm{p}}>0.07 \mathrm{~m}^{-1}\right)$. In contrast to the oligotrophic regime (at $16^{\circ} \mathrm{S}$ ), the DCM is located between $10 \%$ and $1 \%$ PAR levels.

Between $4^{\circ} \mathrm{S}$ and $1^{\circ} \mathrm{N}$ the zonal flow for the upper layers is everywhere oriented to the west, with low speed in the $4^{\circ}-1^{\circ} \mathrm{S}$ band and higher values in the equatorial $\left(1^{\circ} \mathrm{S}-1^{\circ} \mathrm{N}\right)$ belt, particularly between $1^{\circ} \mathrm{S}$ and the equator. The upper layer temperature is still above $28^{\circ} \mathrm{C}$ in this belt. The $4^{\circ}-1^{\circ} \mathrm{S}$ zone is characterized by a thickening of the homogeneous mixed layer with warm waters $\left(\theta>28^{\circ} \mathrm{C}\right.$ and $\left.\sigma<22.58\right)$, nitrate concentration slightly above $2 \mu \mathrm{M}$, and a local $\left(1^{\circ}\right.$ $\left.2^{\circ} \mathrm{S}\right)$ minimum in phytoplankton biomass within the DCM (chl $\left.a<0.35 \mathrm{mg} \mathrm{m}^{-3}\right)$ and in $c_{\mathrm{p}}\left(<0.07 \mathrm{~m}^{-1}\right.$ ).

Around the equator, and particularly between 0 and $1^{\circ} \mathrm{N}$, the situation is markedly different. Brought by the equatorial divergence, nitrogen reaches concentrations of $\sim 3 \mu \mathrm{M}$ at the surface. This equatorial band corresponds to a relative increase in $c_{\mathrm{p}}\left(>0.07 \mathrm{~m}^{-1}\right)$, homogeneously distributed, although these values remain lower than those observed in the $7^{\circ}-3^{\circ} \mathrm{S}$ band (Plate 2). Algae (with chl $a>0.35 \mathrm{mg} \mathrm{m}^{-3}$ at $1^{\circ} \mathrm{N}$ ) are also rather uniformly distributed from 0 down to $90 \mathrm{~m}$ within a layer which actually includes the surface waters flowing westward as well as those belonging to the upper part of the equatorial undercurrent and flowing eastward. This undercurrent, with a core velocity $\left(60 \mathrm{~cm} \mathrm{~s}^{-1}\right)$ at $\sim 170 \mathrm{~m}$ (and extending down to $300 \mathrm{~m}$ ), carries water of northern origin (with a typical salinity minimum of 35.09 practical salinity unit (PSU) at $130 \mathrm{~m}$ ) abruptly replaced by water of southern origin (salinity maximum of 35.34 PSU at $150 \mathrm{~m}$ ). The highest algal biomass and, correlatively, the shallowest euphotic zone $(Z e=65 \mathrm{~m})$ were observed at $1^{\circ} \mathrm{N}$ and not at the equator itself.

Ratioing the vertically integrated values of the $c_{\mathrm{p}}$-derived POC and $F_{\text {is }}$-derived chl $a$ (within layers delimited by the depths corresponding respectively to $10 \%$ and $1 \%$ of surface PAR) leads to the following observations (Figure 4): (1) clear regional differences exist with the highest values recorded in the subtropical gyre (338 g:g) and the lowest 


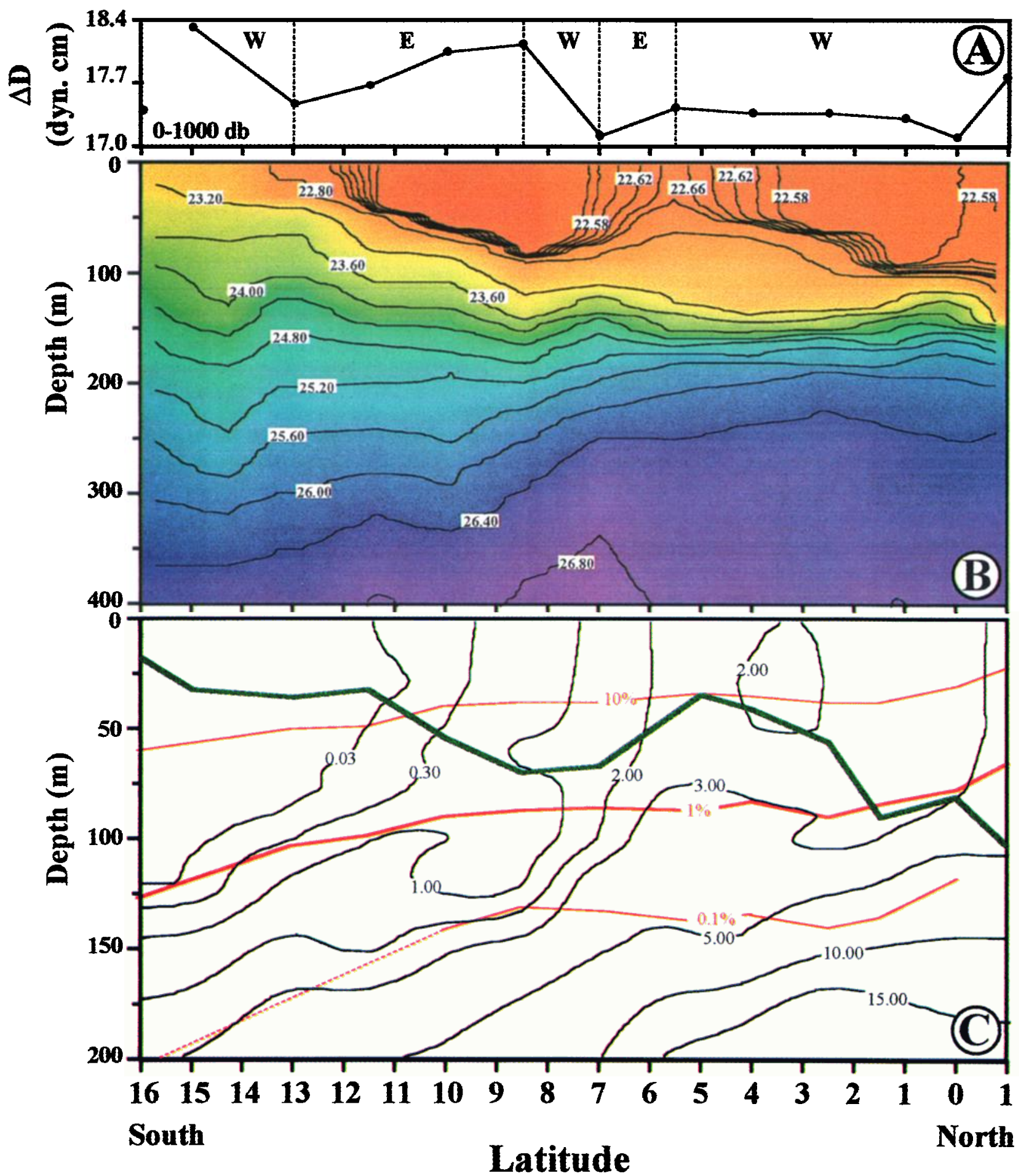

Plate 1. Meridional section along $150^{\circ} \mathrm{W}$ between $16^{\circ} \mathrm{S}$ and $1^{\circ} \mathrm{N}$ : (a) dynamic topography relative to 1000 dbar (the direction of the zonal flow is indicated by the letters $\mathrm{E}$ (eastward) and W (westward)), (b) density excess $\left(\sigma\right.$, as $\left.\mathrm{kg} \mathrm{m}^{-3}\right)$, and (c) nitrate concentration $(\mu \mathrm{M})$ in black and percentage of surface photosynthetic available radiation (PAR) in red. The heavy green line represents the bottom of the mixed layer. Data from the transect $\left(15^{\circ} \mathrm{S}-1^{\circ} \mathrm{N}\right)$ are completed by data at $16^{\circ} \mathrm{S}$ obtained 20 days after the investigation at $15^{\circ} \mathrm{S}$. The continuity of the section between $16^{\circ} \mathrm{S}$ and $15^{\circ} \mathrm{S}$ is therefore only indicative (not shown for dynamic topography). 


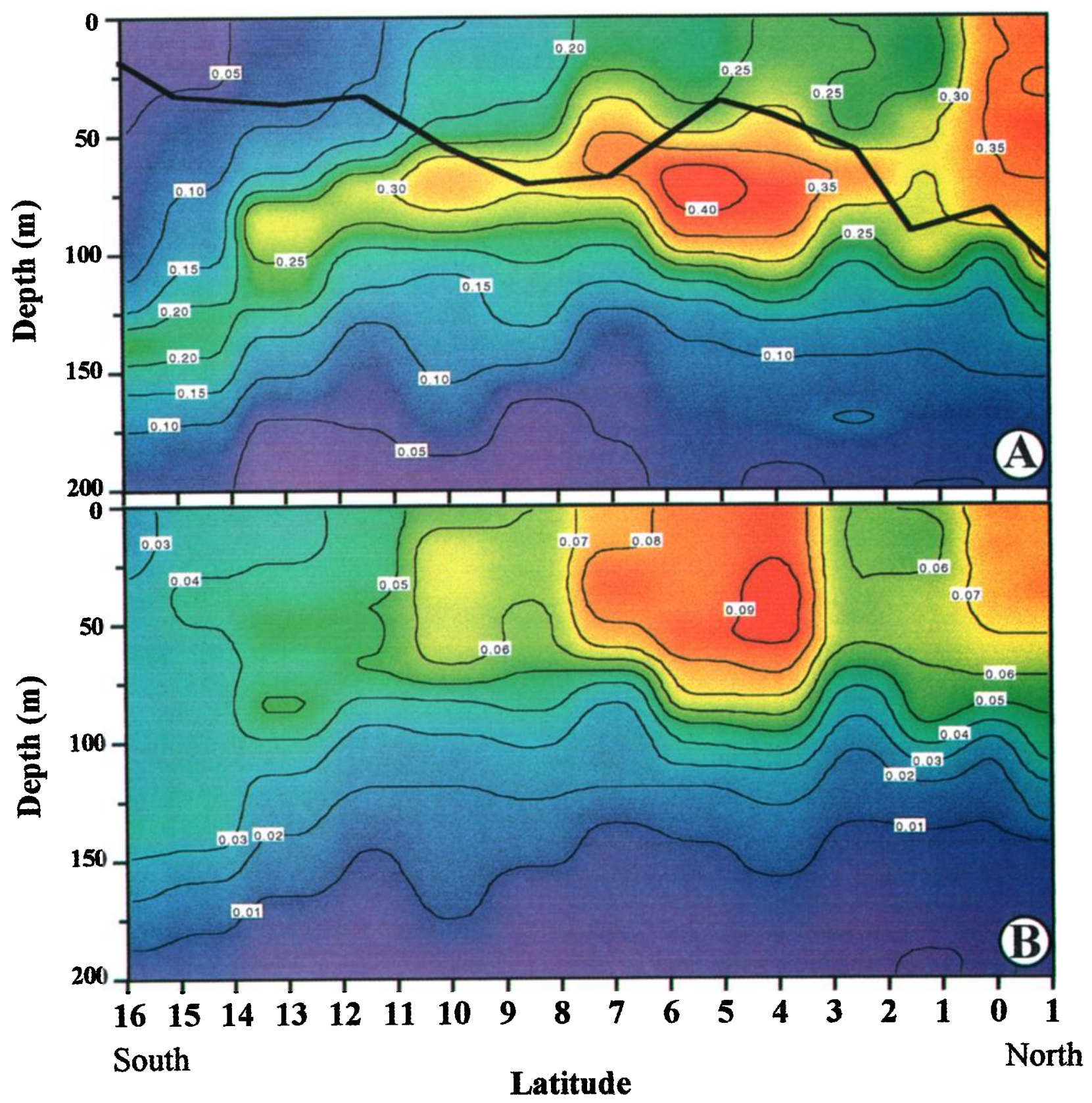

Plate 2. Meridional section along $150^{\circ} \mathrm{W}$ between $16^{\circ} \mathrm{S}$ and $1^{\circ} \mathrm{N}$ : (a) fluorescence (relative units) (the heavy line represents the bottom of the mixed layer) and (b) particle attenuation $\left(\mathrm{m}^{-1}\right)$. Data from the transect $\left(15^{\circ} \mathrm{S}-1^{\circ} \mathrm{N}\right)$ are completed by data at $16^{\circ} \mathrm{S}$ obtained 20 days after the investigation at $15^{\circ} \mathrm{S}$. The continuity of the section between $16^{\circ} \mathrm{S}$ and $15^{\circ} \mathrm{S}$ is therefore only indicative. 


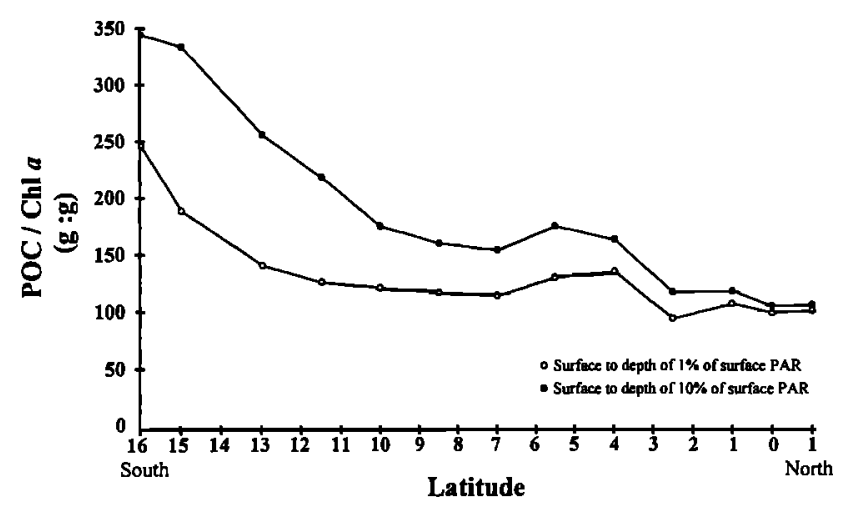

Figure 4. Latitudinal variations of the $\mathrm{POC} / \mathrm{chl} a$ ratio along $150^{\circ} \mathrm{W}$.

at the equator (108 $\mathrm{g}: \mathrm{g}$ ). These ratios have been computed by using exclusively morning profiles (just before sunrise) as some daily variability is recorded in either $c_{\mathrm{p}}$ or in fluorescence (see section 3.4.2). The range of variations in $\mathrm{POC} / \mathrm{chl} a$ ratio as well as the zonal trend are similar to what was reported by Peña et al. [1991], on the basis of carbon and pigment analysis along $135^{\circ} \mathrm{W}$ and by Chung et al. [1996] along $140^{\circ} \mathrm{W}$, who also used $c_{\mathrm{p}}$ as a proxy of POC, however with a $c_{\mathrm{p}}^{\mathrm{c}}$ value differing from that adopted here. These regional differences primarily reflect the change in the trophic status entailing differing balances between algal and nonalgal materials; this change will be examined later in a more quantitative way. (2) The decrease in the POC/chl $a$ ratio, from the south to equator, is not monotonic as relatively higher values compared to those in neighboring areas are observed around $5^{\circ} \mathrm{S}$. (3) In the equatorial zone the ratio is the same whatever the layer considered (from surface to $1 \%$ or $10 \%$ of surface PAR), contrary to the subtropical gyre where the values in the upper layer (PAR $\geq 10 \%$ ) are about twice those computed for the whole photic zone (Figure 4). This result likely reveals regional differences in the balance between mixing rates and photoadaptation rates.

\subsection{Typical Situations Within the Meridional Transect}

The vertical distribution of $F_{\text {is }}$ and $c_{\mathrm{p}}$ is now analyzed for three selected situations differing by hydrodynamic and trophic conditions, namely, the south tropical gyre $\left(16^{\circ} \mathrm{S}\right)$, the divergence at $5^{\circ} \mathrm{S}$, and the equatorial divergence $\left(0^{\circ}\right)$. The three systems exhibit marked differences with respect to the relative positions of the euphotic zone depth $(Z e)$ and of the mixed layer depth $(\mathrm{Zm})$ (Figure 5). At $16^{\circ} \mathrm{S}$ the water column is stratified everywhere, and $Z e$ is at $130 \mathrm{~m}$; in the divergence system, at $5^{\circ} \mathrm{S}, \mathrm{Ze}(85 \mathrm{~m})$ is below $\mathrm{Zm}(55$ $\mathrm{m})$, while the reverse occurs at the equatorial divergence, with $Z e(70 \mathrm{~m})$ above $Z m(80 \mathrm{~m})$. For the three situations considered, $c_{\mathrm{p}}$ and $F_{\text {is }}$ profiles roughly covary below $Z e$, in

$16^{\circ} \mathrm{S}, 150^{\circ} \mathrm{W}$

$5^{\circ} \mathrm{S}, 150^{\circ} \mathrm{W}$

$0^{\circ}, 150^{\circ} \mathrm{W}$
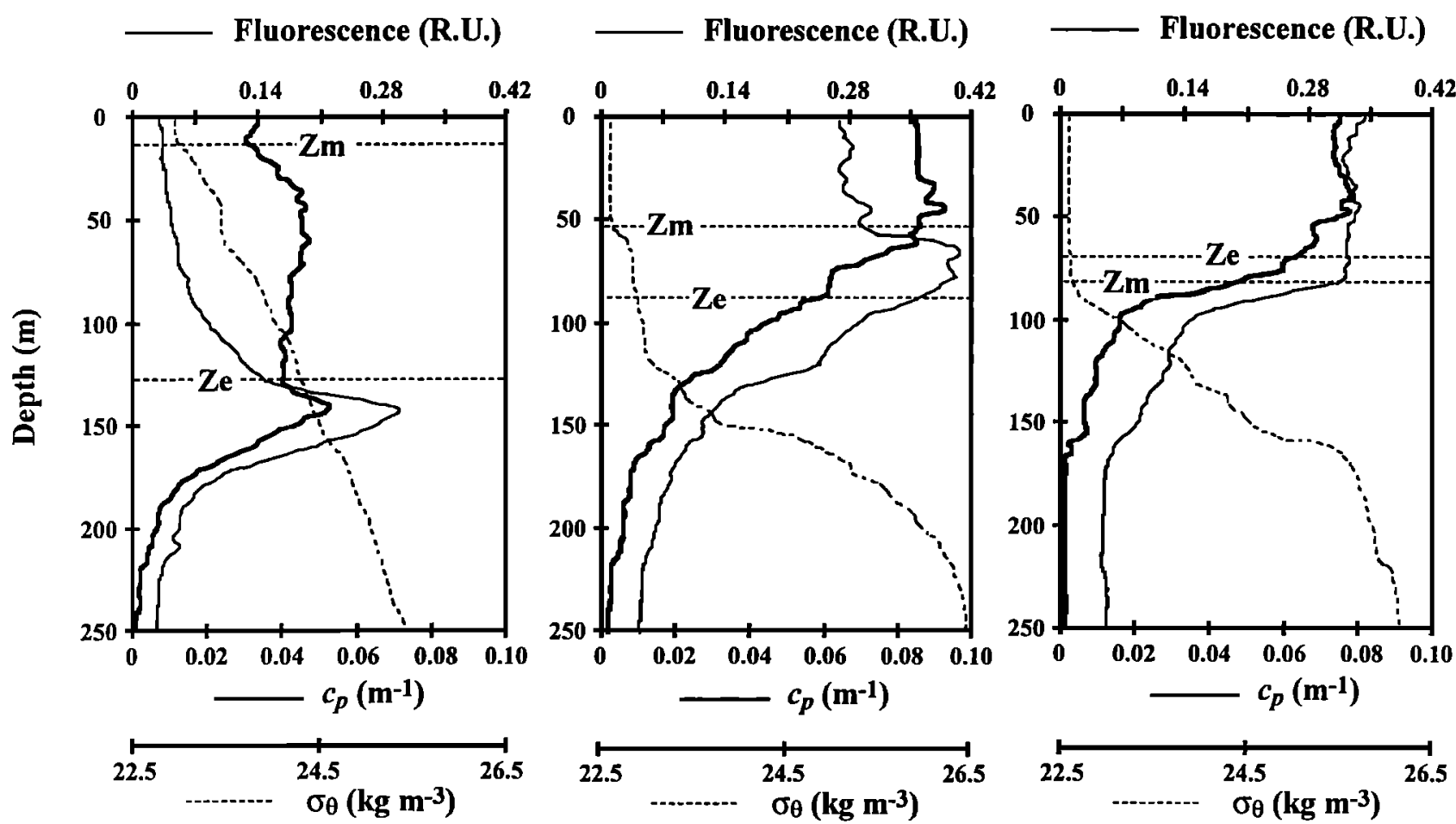

Figure 5. Typical vertical distributions of particle attenuation, fluorescence, and density in three situations representative of the hydrodynamic and trophic conditions investigated during the OLIPAC cruise. The depth of the euphotic zone $(Z e)$, and the lower limit of the mixed layer $(\mathrm{Zm})$ are indicated. 
particular, at $16^{\circ} \mathrm{S}$, where the DCM is associated with a relative particle maximum. The progressive decrease in $F_{\text {is }}$ and $c_{\mathrm{p}}$ with depth (below $150 \mathrm{~m}$ at $16^{\circ} \mathrm{S}$ and below $\mathrm{Ze}$ at $5^{\circ} \mathrm{S}$ and $0^{\circ}$ ) likely reflects a "mixing rule" [Loisel and Morel, 1998], i.e. a progressive downward dilution of the same particle assemblage (vegetal plus nonvegetal). Within the euphotic zone the covariation is no longer the rule, and the behavior of $F_{\text {is }}$ and of $c_{\mathrm{p}}$, which are site-dependent, have to be examined with respect to the light and density fields. At $16^{\circ} \mathrm{S}$, there is a complete absence of correlation between $c_{\mathrm{p}}$ and $F_{\text {is }}$ in this layer. The strong stratification conditions of this stable system possibly lead to (1) a vertical segregation in the vegetal and nonvegetal assemblage and (2) photoadaptation processes inducing increases in chlorophyll cellular content within the algal populations [e.g., Falkowski, 1980]. At $5^{\circ} \mathrm{S}$ $(Z e>Z m), c_{\mathrm{p}}$ and $F_{\text {is }}$ are homogeneously distributed within the mixed layer, which reveals efficient vertical mixing. Below this mixed layer, $c_{\mathrm{p}}$ decreases, while a relative fluorescence maximum develops, again, likely as the result of photoadaptation processes. At the equator (with $Z m>Z e$ ), $F_{\text {is }}$ is quasi-constant within the mixed layer, whereas $c_{\mathrm{p}}$ begins to diminish from $40 \mathrm{~m}$ depth. This lack of correlation tends to demonstrate that vertical mixing does not extend down to the pycnocline so that homogenization is not fully realized.

\subsection{Contribution of the Various Biological Stocks to Particulate Attenuation and in Situ Fluorescence}

Although fluorescence and transmissiometry techniques provide only bulk information, they still possess the advantage of capturing continuous profiles over the entire water column. If flow cytometric techniques can only be applied on discrete samples (12 along the vertical, in the present study), they provide, in contrast, detailed enumeration of the algal groups (Prochlorococcus, Synechococcus and picoeucaryotes) and of heterotrophic bacteria. In what follows, both techniques are combined in order (1) to estimate the vegetal and nonvegetal contribution to $c_{\mathrm{p}}$, (2) to discriminate, within the "vegetal $c_{\mathrm{p}}$ " and the fluorescence signals, the respective roles of the various phytoplanktonic groups, (3) to split the "nonvegetal $c_{\mathrm{p}}$ " signal into heterotrophic organisms and detritic contributions, and (4) finally, to reconstruct, from the $c_{\mathrm{p}}$ and $F_{\text {is }}$ profiles, continuous vertical profiles of these various biological stocks.

3.3.1. Biological stocks and particle attenuation. Attenuation at $660 \mathrm{~nm}$ is predominantly driven (>97\%) by particle scattering [Loisel and Morel, 1998]. Therefore, when decomposing $c_{\mathrm{p}}$ in its various microbial components, the prerequisite is the estimation of their typical scattering cross section. Such decomposition was already performed by Chung et al. [1996], who made use of the scattering cross sections of various microbes (at $550 \mathrm{~nm}$ ) published by Stramski and Kiefer [1991]; recently, DuRand and Olson [1996] and Chung et al. [1998] also derived scattering cross sections from the forward light scatter (FLS) signals measured by flow cytometry. In the present study the efficiency factor for scattering ( $Q_{\mathrm{b}}$, dimensionless) was computed (at $660 \mathrm{~nm}$ ) through the anomalous diffraction approx- imation [Van de Hulst, 1957] for "generic" cells assumed to be representative for each identified category. Namely, heterotrophic bacteria, Prochlorococcus, Synechococcus and picoeucaryotes were assumed to be spherical with mean diameters equal to 0.50, 0.70, 1.20 [Morel and Ahn, 1991; Morel et al., 1993], and $2.28 \mu \mathrm{m}$ [Simon et al., 1994; Campbell et al., 1994], respectively. The relative index of refraction was supposed to be 1.05 for all organisms, and the resulting scattering cross sections, $\sigma_{\mathrm{b}}\left(Q_{\mathrm{b}}\right.$ times the geometrical cross section), are $9.93 \times 10^{-15}, 3.79 \times 10^{-14}$, $3.21 \times 10^{-13}$, and $3.84 \times 10^{-12} \mathrm{~m}^{2}$ cell $^{-1}$ for heterotrophic bacteria, Prochlorococcus, Synechococcus and picoeucaryotes, respectively. The partial scattering (or equivalently attenuation) coefficient, $b$, is computed as $b=N / V \sigma_{\mathrm{b}}$, were $N / V$ represents the numerical abundance (cell $\mathrm{m}^{-3}$ ) of the organism considered. Bigger heterotrophic organisms (flagellates and ciliates) were not enumerated. In an attempt to quantify their effect the values given by Morel and Ahn [1991] were adopted. According to various hypotheses concerning the size and the relative abundance within the heterotrophic compartment, the cumulated (bacteria + flagellates + ciliates) contribution to scattering would be between 1.8 and 2.4 times that of the sole heterotrophic bacteria contribution [Morel and Ahn, 1991, Table 2]. Here, a factor of 2 has been adopted.

The three autotrophic groups measured by flow cytometry (Prochlorococcus, Synechococcus, and picoeucaryotes) are assumed to be representative of the whole vegetal material, to the extent that larger algal species (diatoms, dinoflagellates), as depicted by pigment markers (fucoxanthin, peridinin), were scarce [Cailliau, 1996]. Therefore the vegetal fraction of $c_{\mathrm{p}}$, hereafter denoted " $c_{\mathrm{veg}}$ ", actually is the sum of the partial contributions computed for each autotrophic group : $c_{\mathrm{veg}}=c_{\text {pro }}+c_{\text {syn }}+c_{\text {pico }}$ (where the subscripts pro, syn and pico refer to Prochlorococcus, Synechococcus and picoeucaryote populations, respectively). The nonvegetal fraction of $c_{\mathrm{p}}$, denoted " $c_{\text {nveg", }}$, is then estimated as the difference $c_{\text {nveg }}=c_{\mathrm{p}}-c_{\mathrm{veg}}$. This fraction can now be splitted into a contribution from heterotrophic bacteria " $c_{\text {bact }}$ " a cumulated contribution of all heterotroph " $c_{\text {het }}$ " $\left(c_{\text {het }}=2 c_{\text {bact }}\right.$, see above), and a contribution by nonidentified particles denoted $c_{\operatorname{det}}$ (Table 1). Indeed various detritus (and possibly bubbles) [Stramski, 1994], are likely responsible for this last term which appears to be predominant (Figure 6 and Table 1).

The balance between the nonvegetal and vegetal compartments can be assessed for the three typical situations; the relative contributions (\%) are provided in Table 1 , and the partial attenuation values $\left(\mathrm{m}^{-1}\right)$ are displayed in Figures 6 and 7a. It is worth noting that if $c_{\text {nveg }}$ is roughly the same in the upper layers at the three stations, $c_{\text {veg }}$ changes markedly. As a result, within the euphotic zone the proportion of vegetal material is $43 \%$ at the equator, $39 \%$ at $5^{\circ} \mathrm{S}$, and as low as $20 \%$ at $16^{\circ} \mathrm{S}$. Below $\mathrm{Ze}$, the nonalgal material progressively predominates. This result is in agreement with the observation made by $D u R$ and and Olson [1996] at an equatorial station at $140^{\circ} \mathrm{W}$; DuRand and Olson found equivalent contributions of vegetal and nonvegetal material to the formation 
Table 1. Contribution of Different Particulate Stocks to Attenuation for Three Oceanic Situations Along $150^{\circ} \mathrm{W}$

\begin{tabular}{|c|c|c|c|c|c|c|c|c|c|}
\hline \multirow[b]{2}{*}{ Layer } & \multirow[b]{2}{*}{ Latitude } & \multicolumn{4}{|c|}{ Vegetal Pool } & \multicolumn{4}{|c|}{ Nonvegetal Pool } \\
\hline & & $c_{\text {pro }}$ & $c_{\text {syn }}$ & $c_{\text {pico }}$ & $c_{\text {veg }}$ & $c_{\text {bact }}$ & $c_{\text {het }}$ & $c_{\text {det }}$ & $c_{\text {nveg }}$ \\
\hline $0-25 \mathrm{~m}$ & $\begin{array}{c}0^{\circ} \\
5^{\circ} \mathrm{S} \\
16^{\circ} \mathrm{S}\end{array}$ & $\begin{array}{l}8 \\
8 \\
6\end{array}$ & $\begin{array}{l}5 \\
9 \\
1\end{array}$ & $\begin{array}{c}30 \\
22 \\
6\end{array}$ & $\begin{array}{l}43 \\
39 \\
13\end{array}$ & $\begin{array}{c}7 \\
9 \\
16\end{array}$ & $\begin{array}{l}15 \\
18 \\
31\end{array}$ & $\begin{array}{l}42 \\
43 \\
56\end{array}$ & $\begin{array}{l}57 \\
61 \\
87\end{array}$ \\
\hline $0-Z e^{a}$ & $\begin{array}{c}0^{\circ} \\
5^{\circ} \mathrm{S} \\
16^{\circ} \mathrm{S}\end{array}$ & $\begin{array}{c}8 \\
8 \\
12\end{array}$ & $\begin{array}{l}5 \\
8 \\
1\end{array}$ & $\begin{array}{c}30 \\
23 \\
7\end{array}$ & $\begin{array}{l}43 \\
39 \\
20\end{array}$ & $\begin{array}{c}8 \\
9 \\
12\end{array}$ & $\begin{array}{l}16 \\
18 \\
25\end{array}$ & $\begin{array}{l}41 \\
43 \\
55\end{array}$ & $\begin{array}{l}57 \\
61 \\
80\end{array}$ \\
\hline
\end{tabular}

Data are expressed in percenrage of $c_{\mathrm{p}}\left(c_{\mathrm{p}}=c_{\mathrm{veg}}+c_{\mathrm{nveg}}\right.$ ). The various subscripts refer to Prochlorococcus (pro), Synechococcus (syn), picoeucaryotes (pico), vegetal material (veg), heterotrophic bacteria (bact), heterotrophs (het; includes heterotrophic bacteria, flagellates, and ciliates), detritus (det), and nonvegetal material (nveg), so that $c_{\mathrm{veg}}=c_{\text {pico }}+c_{\text {syn }}+c_{\text {pro }}$ and $c_{\text {nveg }}=c_{\text {het }}+c_{\text {det }}$ with $c_{\text {het }}=2 c_{\text {bact }}$.

a $Z e$ corresponds to the depth of the euphotic zone.

of $c_{\mathrm{p}}$ in surface layer, while at depth $(100 \mathrm{~m})$ the attenuation signal was essentially caused by nonalgal material. At $16^{\circ} \mathrm{S}$ the vertical $c_{\text {nveg }}$ pattern exhibits two relative maxima at $\sim$ $30 \mathrm{~m}$ and within the DCM $(135 \mathrm{~m})$. The reduced contribution of algal material (and correlatively the higher proportion of nonalgal material) in the subtropical gyre, compared to the two divergence zones, is a clear evidence of trophic status differences. The divergence zone generates rather "new" systems of production, as a minimal nutrient flux can sustain algal growth. In contrast, the subtropical gyre is typical of an "old" system of production, essentially fueled by its own regenerative capabilities, and based on the microbial loop activity. Indeed, the various components of the microbial loop in the euphotic zone, as estimated by $c_{\text {het }}$, represent $25 \%$ of $c_{\mathrm{p}}$ at $16^{\circ} \mathrm{S}$ instead of $18 \%$ or $16 \%$ at the $5^{\circ} \mathrm{S}$ diver- gence or at the equator, respectively. The difference is even greater when considering the upper layer $(0-25 \mathrm{~m})$ (Table 1). Nevertheless, it appears that the nonalgal pools remain dominated by the contribution of largely unknown (detritic) particles which would account, within the euphotic zone, for $55 \%$ of the $c_{\mathrm{p}}$ value at $16^{\circ} \mathrm{S}$ and for more than $40 \%$ in the two divergence systems.

With regard to the algal compartment the role of the three identified organisms are site-dependent. At the equator, $c_{\text {pico }}$ is nearly constant $\left(0.022 \mathrm{~m}^{-1}\right)$ within the top $60 \mathrm{~m}$ where it represents $69 \%$ of $c_{\mathrm{veg}}$; Prochlorococcus and Synechococcus contributions amount only to $19 \%$ and $12 \%$, respectively (Figure 7a and Table 1). DuRand and Olson [1996] also found that picoeucaryotes are the main contributors to the vegetal signal at the equator, while the role of Prochloro-

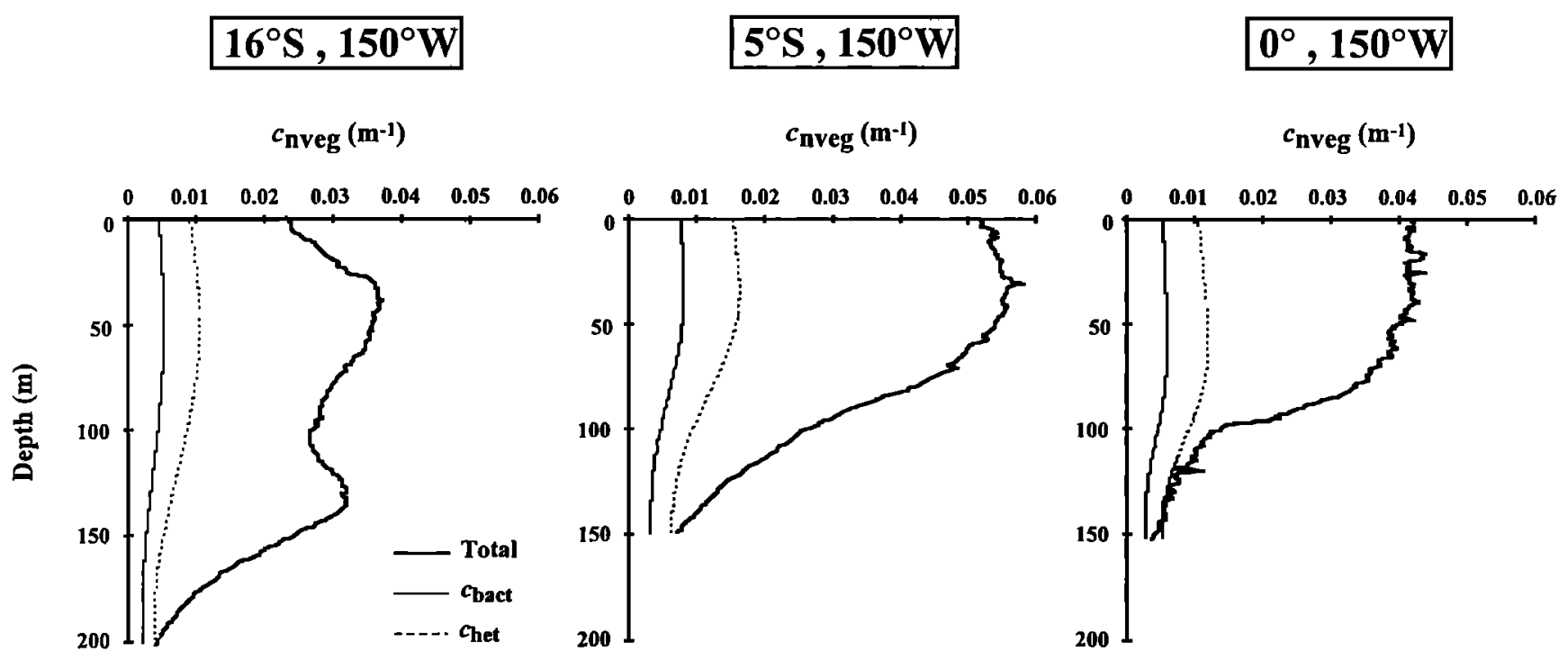

Figure 6. Decomposition of the nonvegetal component of particle attenuation into its major contributors for three typical oceanic conditions (see text). These vertical profiles are based on mean night $c_{\text {p }}$ profiles (average of 3 profiles at $0^{\circ}, 24$ at $5^{\circ} \mathrm{S}$, and 20 at $16^{\circ} \mathrm{S}$ ) and mean depth distributions of heterotrophic bacteria enumeration ( $\left(9\right.$ samples at $0^{\circ}, 224$ at $5^{\circ} \mathrm{S}$ and 134 at $16^{\circ} \mathrm{S}$ ). 


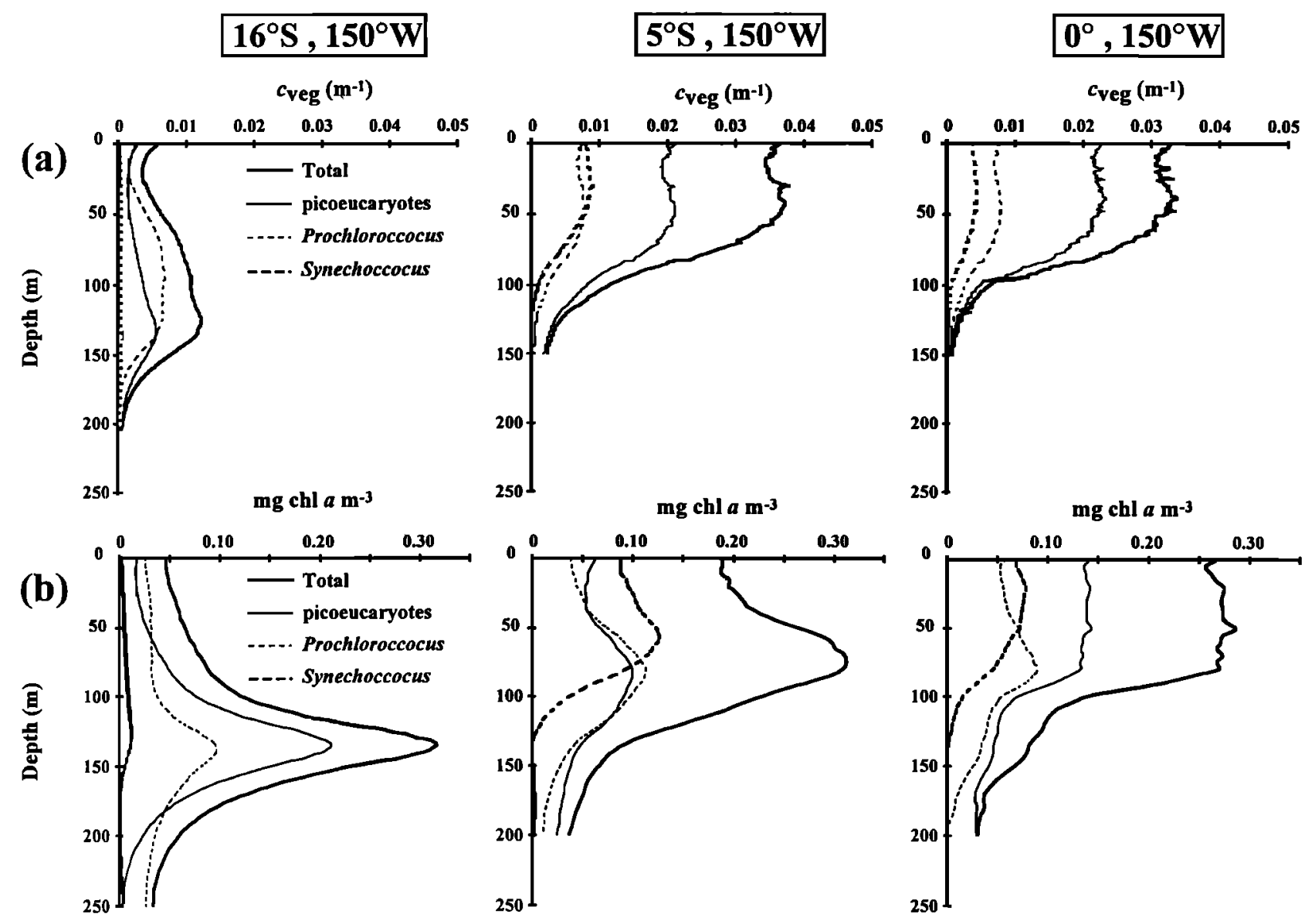

Figure 7. Decomposition of the vegetal component of (a) particle attenuation and (b) chl $a$ calibrated fluorescence into their major phytoplanktonic contributors for the three typical oceanic conditions. These vertical profiles are based on mean night $c_{\mathrm{p}}$ or $F_{\text {is }}$ profiles (average of 3 profiles at $0^{\circ}, 24$ at $5^{\circ} \mathrm{S}$ and 20 at $\left.16^{\circ} \mathrm{S}\right)$ and mean depth distributions of phytoplankton groups (11 samples at $0^{\circ}, 224$ samples at $5^{\circ} \mathrm{S}$, and 286 samples at $16^{\circ} \mathrm{S}$ ).

coccus is smaller and that of Synechococcus would be negligible. At $5^{\circ} \mathrm{S}$, picoeucaryotes are again the major coniributor to $c_{\text {veg }}$ (more than $57 \%$ in the top $150 \mathrm{~m}$ layer), and $c_{\text {syn }}$ and $c_{\text {pro }}$ are nearly the same, each contributing to about $20 \%$ of $c_{\text {veg. }}$. At $16^{\circ} \mathrm{S}$ the contribution of Synechococcus is almost negligible. Between 0 and $30 \mathrm{~m}$, Prochlorococcus and picoeucaryote populations are of similar importance (note, however, that Prochlorococcus cells cannot be reliably enumerated in the upper layer because of their weak fluorescence signal). The Prochlorococcus population becomes the main contributor to $c_{\mathrm{veg}}$ between 50 and $135 \mathrm{~m}$ whereas picoeucaryotes are dominant beyond $135 \mathrm{~m}$. Inside the $\mathrm{DCM}, c_{\text {pico }}\left(0.006 \mathrm{~m}^{-1}\right)$ is maximum and contributes $50 \%$ of $c_{\text {veg. }}$. This picoeucaryote maximum coincides with the upper boundary of the nitracline (Plate 1) as previously observed [Claustre and Marty, 1995] in a similar environment of the North Atlantic gyre. This observation led to the proposition that picoeucaryotes (in particular, pelagophytes) could be responsible for the new production linked to a regular diffusion of nitrate in this impoverished environment.

It is worth noting that the assumptions regarding the size of the various particles identified by flow cytometry are cru- cial in the analysis of the $c_{\mathrm{p}}$ signal and its decomposition. Nonetheless, such assumptions are inevitable because (1) of the paucity of in situ measurements of individual population size and (2) the possibility of size determinations performed on culture isolates being biased by growing conditions differing from those found in situ. For Prochlorococcus and heterotrophic bacteria the study of Chung et al. [1998] led to sizes similar to those used as input in our calculation. For Synechococcus their value $(0.90 \mu \mathrm{m})$, slightly lower than ours $(1.2 \mu \mathrm{m})$, has little impact on the estimated contribution of Synechococcus, which, anyway, is reduced. The main uncertainty when decomposing $c_{\mathrm{p}}$ results from picoeukaryotes. For these organisms the mean size estimated by Chung et al. [1998] $(1.26 \mu \mathrm{m})$ is much lower than the one used as input in our calculation $(2.28 \mu \mathrm{m})$ and based on microscopic size measurements performed on natural populations (HOTS station) [Campbell et al., 1994]. This difference in size leads to a tremendous difference in scattering cross sections, actually by a factor of 10 . As a consequence, the estimate of the picoeukaryote contribution is 10 times lesser when a size of $1.26 \mu \mathrm{m}$ is used instead of $2.28 \mu \mathrm{m}$, and the nonvegetal and detrital contributions would be accordingly enhanced. Com- 
pared to this size effect, the hypothesis made about the relative index of refraction (actually less varying) has a minor impact.

3.3.2. Biological stocks and fluorescence. The fluorescence of a population is operationally defined and then computed as the product of phytoplankton fluorescence per cell and of cell concentration. Both quantities are derived from cytometric determinations. The total fluorescence associated with the three phytoplankton groups resolved by flow cytometry, denoted $F_{\text {cyt }}$, can thus be expressed as : $F_{\text {cyt }}=F_{\text {pro }}+$ $F_{\text {pico }}+F_{\text {syn }}$, (subscript meanings as above). As for $c_{\text {veg }}, F_{\text {cyt }}$ is expected to represent the whole vegetal material to the extent that other algal groups can be neglected (see section 3.3.1.).

Because of the difference in photosystem II responses to saturating excitation flashes of various durations and intensities, the fluorescence signals recorded by the cytometer and by the SeaTech fluorometer are not identical, albeit akin [Neale et al., 1989]. Moreover, both are expressed in relative units, which makes direct comparisons impossible. However, the rough linear relationship observed beteween $F_{\text {cyt }}$ and $F_{\text {is }}$ during this cruise (transect plus 5 day stations, $n=721$, Figure 8) suggests that both measurements are consistent. Specific analyses (not detailed here) have not revealed any regional disparity in this relationship, so that the regression line is considered, in spite of a rather large scatter, as valid in all situations. As $F_{\text {is }}$ has been calibrated in chl $a$-equivalent units (see Figure 3 ), $F_{\text {cyt }}$ can accordingly be translated in chl $a$ units. Moreover, if it is assumed that for these small organisms one unit of $F_{\text {pro }}, F_{\text {pico }}$, or $F_{\text {syn }}$ corresponds to same amount of $\operatorname{chl} a$, the chl $a$ biomass associated with each autotrophic group can be tentatively derived (Figure $7 b$ ).

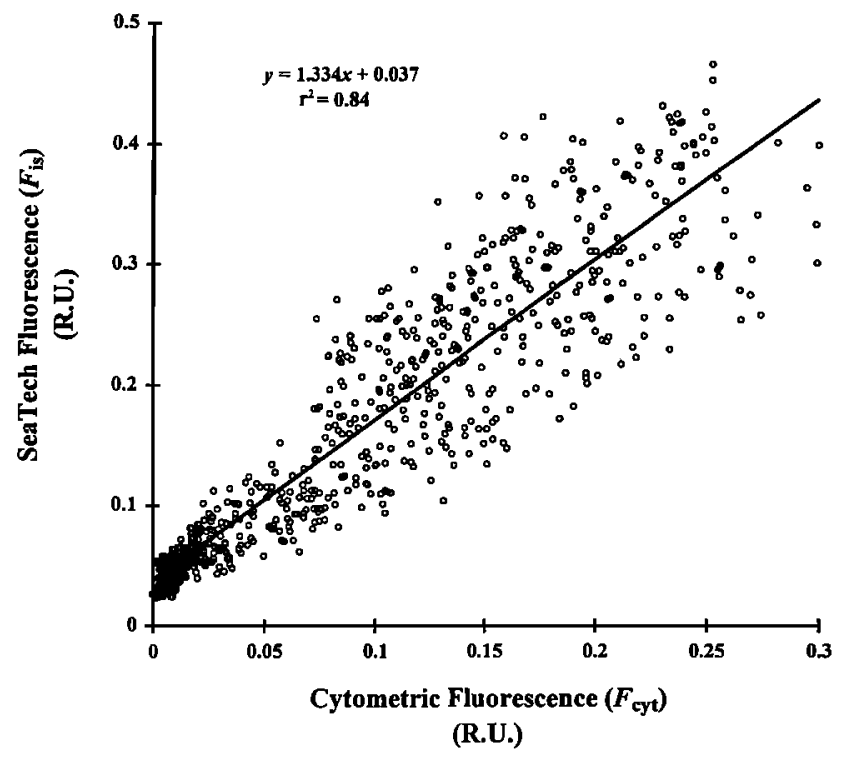

Figure 8. Cytometric fluorescence plotted versus in situ SeaTech fluorescence. The cytometric fluorescence corresponds to the sum of the fluorescence of the three phytoplankton populations (Prochlorococcus, Synechococcus, and picoeucaryotes) calculated as the product of the red fluorescence per cell and cell concentration.
At the equator, the chl $a$ of picoeucaryotes nearly represent $50 \%$ of the total chl $a$ biomass from the surface down to $150 \mathrm{~m}$ (Figure 7b). The chl $a$ of Prochlorococcus shows a relative maximum $\left(0.09 \mathrm{mgchl} a \mathrm{~m}^{-3}\right)$ at the base of the mixed layer $(80 \mathrm{~m})$, while the chl $a$ of Synechococcus is rather constant in the top $50 \mathrm{~m}\left(0.07 \mathrm{mgchl} a \mathrm{~m}^{-3}\right)$ and regularly decreases below. At $5^{\circ} \mathrm{S}$, Synechococcus is the dominant contributor to the chl $a$ in the surface layer (50\% of the total within the top $50 \mathrm{~m}$ ). At the DCM level $(75$ m) the three populations contribute equally (each with $0.10 \mathrm{mgchl} a \mathrm{~m}^{-3}$ ) to the total biomass. Below this maximum, Synechococcus chl $a$ biomass decreases rapidly, thus Prochlorococcus and picoeucaryotes become the only remaining contributors to the total chl $a$. At $16^{\circ} \mathrm{S}$ the Synechococcus contribution is always $<8 \%$ of the total chl $a$. Picoeucaryotes are dominant from 50 to $180 \mathrm{~m}$ including the $\operatorname{DCM}(135 \mathrm{~m})$, where their chl $a\left(0.21 \mathrm{mgchl} a \mathrm{~m}^{-3}\right)$ roughly represents two thirds of the total chl $a$. The Prochlorococcus contribution is preponderant in very deep layers, i.e., between 180 and $250 \mathrm{~m}$.

3.3.3. Comparison of two algal indices: $c_{\text {veg }}$ versus fluorescence. The comparison of Figures $7 \mathrm{a}$ and $7 \mathrm{~b}$ highlights that fluorescence and $c_{\text {veg }}$ are seldom equivalent estimators of algal biomass either in terms of total algal material abundance or in terms of composition. Some previous works have shown that total particles, as estimated by $c_{\mathrm{p}}$, and vegetal material, as estimated by chl $a$, are rarely correlated, particularly along the vertical axis [Pak et al., 1988; Kitchen and Zaneveld, 1990; Morel et al., 1993]. The best instance of such lack of correlation is provided by the chlorophyll maximum concentration, identical for the three situations ( $\sim 0.3 \mathrm{mgchl} a \mathrm{~m}^{-3}$ ), although the $c_{\text {veg }}$ maximum value is nearly 3 times less at the oligotrophic site $\left(0.014 \mathrm{~m}^{-1}\right)$ than at the equator $\left(0.043 \mathrm{~m}^{-1}\right)$ or at $5^{\circ} \mathrm{S}\left(0.045 \mathrm{~m}^{-1}\right)$ (Figure 7). The DCM is often considered to be a consequence of phytoplankton photoadaptation to dim light and does not reflect a proportional carbon increase [Cullen, 1982; Kitchen and Zaneveld, 1990; Claustre and Marty, 1995]. At $16^{\circ} \mathrm{S}$, nevertheless, the DCM is a (relative) maximum in terms of vegetal attenuation by algae and, consequently, in terms of vegetal carbon. The main part of this signal is due to picoeucaryotes.

The discrepancy between fluorescence- and $c_{\mathrm{p}}$-based estimations of the vegetal biomass is also obvious at the level of specific population and, again, has to be interpreted in the frame of phytoplankton photoadaptation. While the vertical profiles of $F_{\text {pico }}$ and $c_{\text {pico }}$ at $16^{\circ} \mathrm{S}$ are significantly correlated [ $p<0.001$ and $r^{2}=0.82$ ], this is no longer the case for $F_{\text {pro }}$ and $c_{\text {pro }}$ (Figure 7). As shown by Campbell and Vaulot [1993], the increase with depth in the chlorophyll cellular content of picoeucaryotes is much less (10 times less) than in Prochlorococcus. In other words, chl $a$ could be a more reliable estimator of carbon biomass for picoeucaryotes than for Prochlorococcus.

\subsection{Local Variations in Particle Attenuation and Fluorescence}

The above analysis of the meridional transect (Plates 1 and 2) as well as of some specific situations (Figures 5, 6 

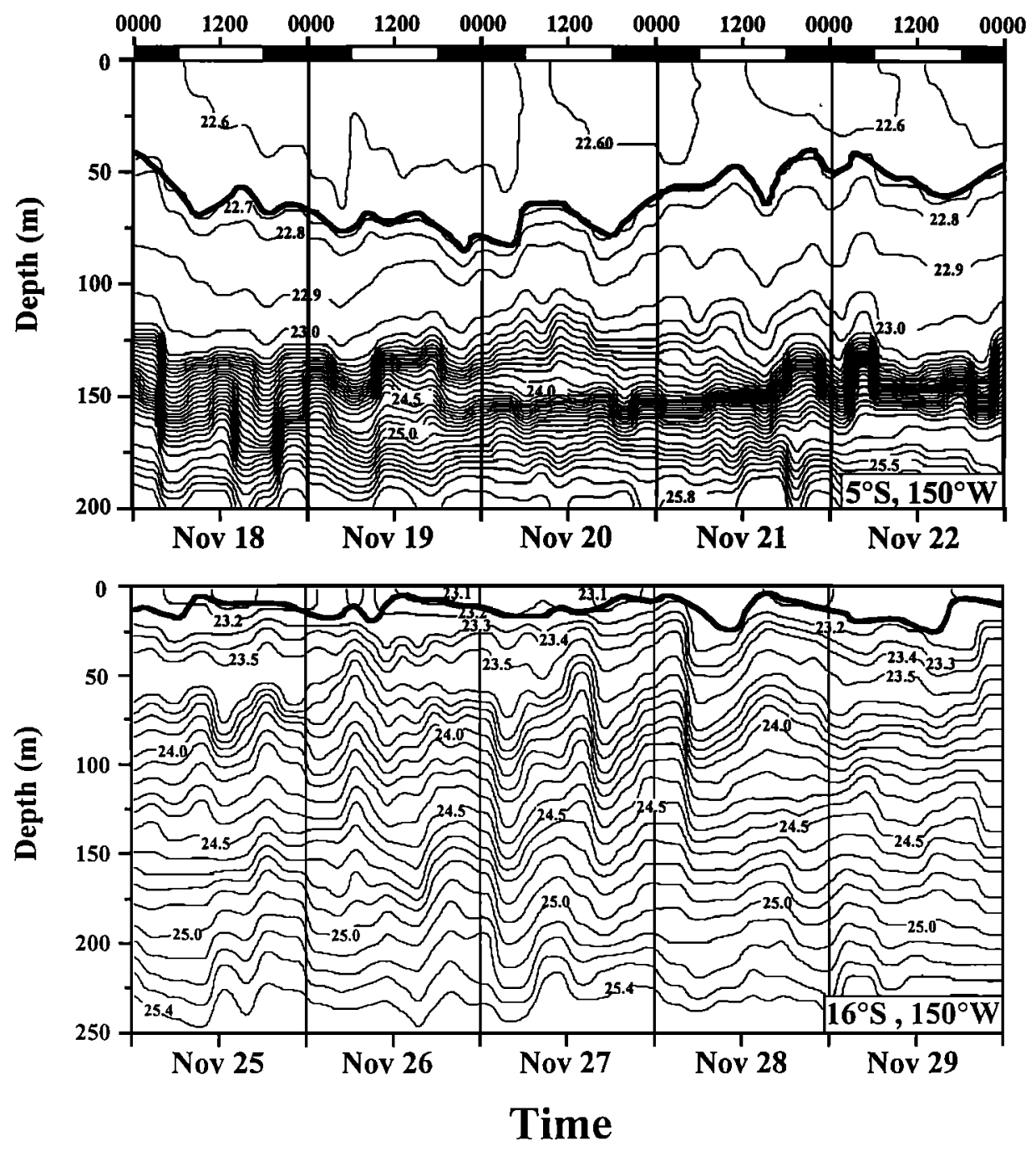

Figure 9. Temporal evolution of the vertical distribution of density $\left(\mathrm{kg} \mathrm{m}^{-3}\right)$ at $5^{\circ} \mathrm{S}$ and $16^{\circ} \mathrm{S}$. The average frequency of data acquisition was 8 profiles $\mathrm{d}^{-1}$. The heavy lines correspond to the bottom of the mixed layer, $\mathrm{Zm}$.

and 7) has shown that the trophic status is the source of wide variations in $c_{\mathrm{p}}$ and $F_{1 \mathrm{~s}}$. The second source of variations, which is related to biological and physiological responses at high frequency, is now analyzed. With this purpose the two 5 day stations, with differing physical (Figure 9) and trophic conditions are examined. Associated with the divergence, a quasi-mesotrophic regime prevails at $5^{\circ} \mathrm{S}$, whereas at $16^{\circ} \mathrm{S}$, within the northern branch of the South Pacific gyre, ultraoligotrophic conditions are observed.

3.4.1. Density-driven vertical patterns. For both stations, the evolution of the vertical distribution of the particle attenuation and fluorescence are displayed either along the geometrical depth or along a density scale (Plates 3 and 4); the density fields are displayed in Figure 9.

At $5^{\circ} \mathrm{S}$ the particle content depicted by $c_{\mathrm{p}}$ remains high in the upper layer from the surface down to a variable depth (40-70 m) which corresponds to $\sigma=22.70$ (Figure 9) and to a first step in the density profile (see also Figure 5). Vertical mixing in this mixed layer results in a rather homogenous vertical $c_{\mathrm{p}}$ distribution. A few meters below and centered on the isopycnal $\sigma=22.80$ the maximum $F_{\text {is }}$ corresponds to the core of the DCM. The maxima in algal biomass are not reflected by $c_{\mathrm{p}}$, which steadily decreases downward. The main pycnocline at this location (with a sharp density gradient from 23.1 to 25.0) begins at $120-135 \mathrm{~m}$ (Figure 9), paralleled by the $c_{\mathrm{p}}=0.02 \mathrm{~m}^{-1}$ and $F_{\text {is }}=0.2$ isolines (Plate 3 ). This interface experiences well-marked oscillations (dominated by a semidiurnal period) with an amplitude of $\sim 15 \mathrm{~m}$, except during the third and the fourth days, when the density gradient is halved $\left(0.03\right.$ versus $\left.0.07 \mathrm{~kg} \mathrm{~m}^{-4}\right)$ and the salinity maximum is split into two maxima (150 and $160 \mathrm{~m}$; data not shown). This event, perhaps a breaking of internal waves, leaves the water masses themselves unaffected (no changes in the $\theta$-S relationship within the upper layers) but makes the DCM shallower and the mixed layer thinner.

Superimposed on the density-driven patterns, circadian cycles are present (Plate 3 ). Within the mixed layer, $c_{\mathrm{p}}$ exhibits a minimum at sunrise and a maximum at sunset. In the DCM, $F_{\text {1s }}$ follows a similar pattern, whereas in the surface layer $(0-25 \mathrm{~m})$, this signal is depressed at noon.

At $16^{\circ} \mathrm{S}$ the mixed layer is about $20 \mathrm{~m}$ thick; below, an almost constant vertical density gradient (Figure 9) ensures 


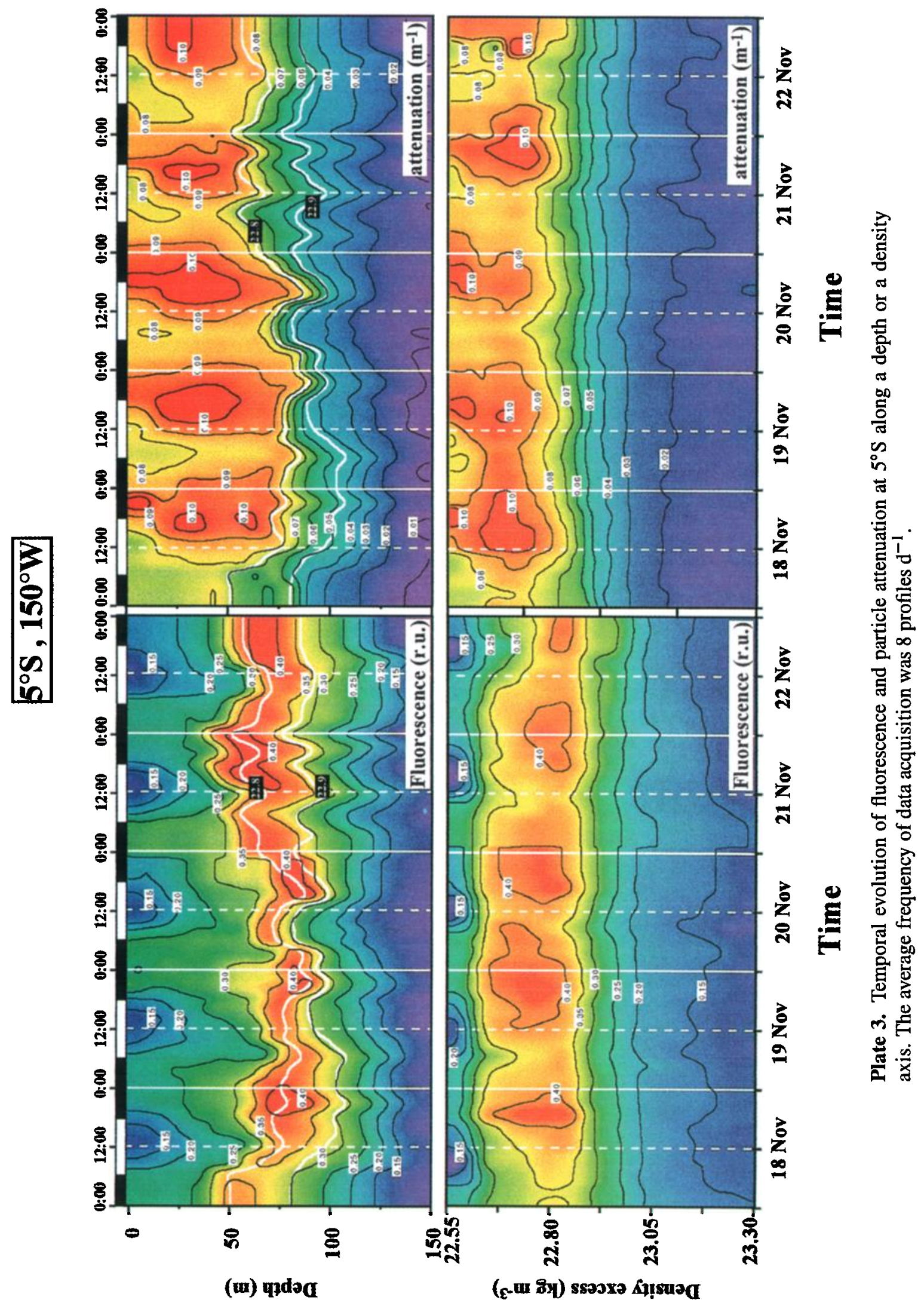




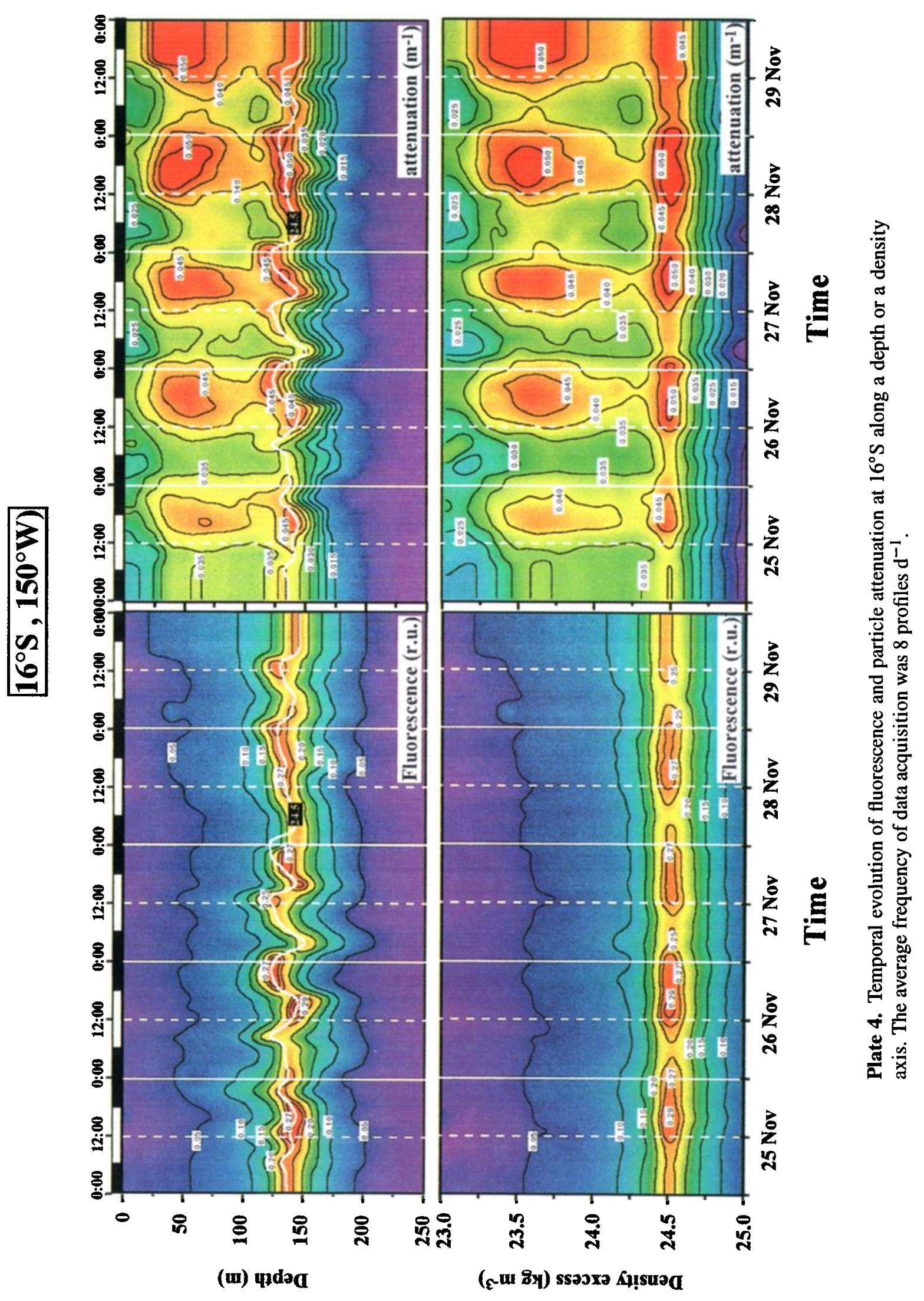


a stable stratification. The whole density field exhibits a semidiurnal oscillation, irregular in amplitude and slightly damped near the surface. The DCM, marked by a relative maximum in $c_{\mathrm{p}}$ and a strong signal in $F_{\mathrm{is}}$, fluctuates between 125 and $150 \mathrm{~m}$, in phase with the 24.5 isopycnal oscillation. Another core of particle accumulation (without fluorescence signal) is centered on $50 \mathrm{~m}(\sigma \approx 23.60)$ on the average; with a vertical extension of $\sim 60 \mathrm{~m}$ (from 30 to $90 \mathrm{~m}$ ), this core is clearly separated from the DCM. Within the DCM the circadian variations in $c_{\mathrm{p}}$ and $F_{\text {is }}$ are in phase, with a maximum in the late afternoon and a minimum at the sunrise.

3.4.2. Daily patterns related to biological processes. In the two sites the daily changes in $c_{\mathrm{p}}$ (transformed into POC) and in $F_{\text {is }}$ are analyzed (Figures 10 and 11) through the temporal variations of their values after integrating over two layers: (1) the surface layer $(0-25 \mathrm{~m})$, where cellular physiological characteristics [Vaulot and Marie, this issue] as well as $F_{\text {is }}$ (Plate 3) present a clear diel cycle and (2) the euphotic layer $(0 \mathrm{~m}$ to $Z e)$. It must be noted that integrating $c_{\mathrm{p}}$ over a given depth interval $(0-25 \mathrm{~m}$ and $0-Z e)$ leads to an optical thickness $\tau_{\mathrm{p}}$ (dimensionless) related to the presence of scattering particles:

$$
\tau_{\mathrm{p}}=\int_{0}^{25, Z e} c_{\mathrm{p}}(z) d z
$$

When the carbon-specific attenuation coefficient is introduced, with $c_{\mathrm{p}}=c_{\mathrm{p}}^{\mathrm{c}}$ [POC], the above expression is transformed into

$$
\tau_{\mathrm{p}}=c_{\mathrm{p}}^{\mathrm{c}} \int_{0}^{25, Z e} \operatorname{POC}(z) d z
$$

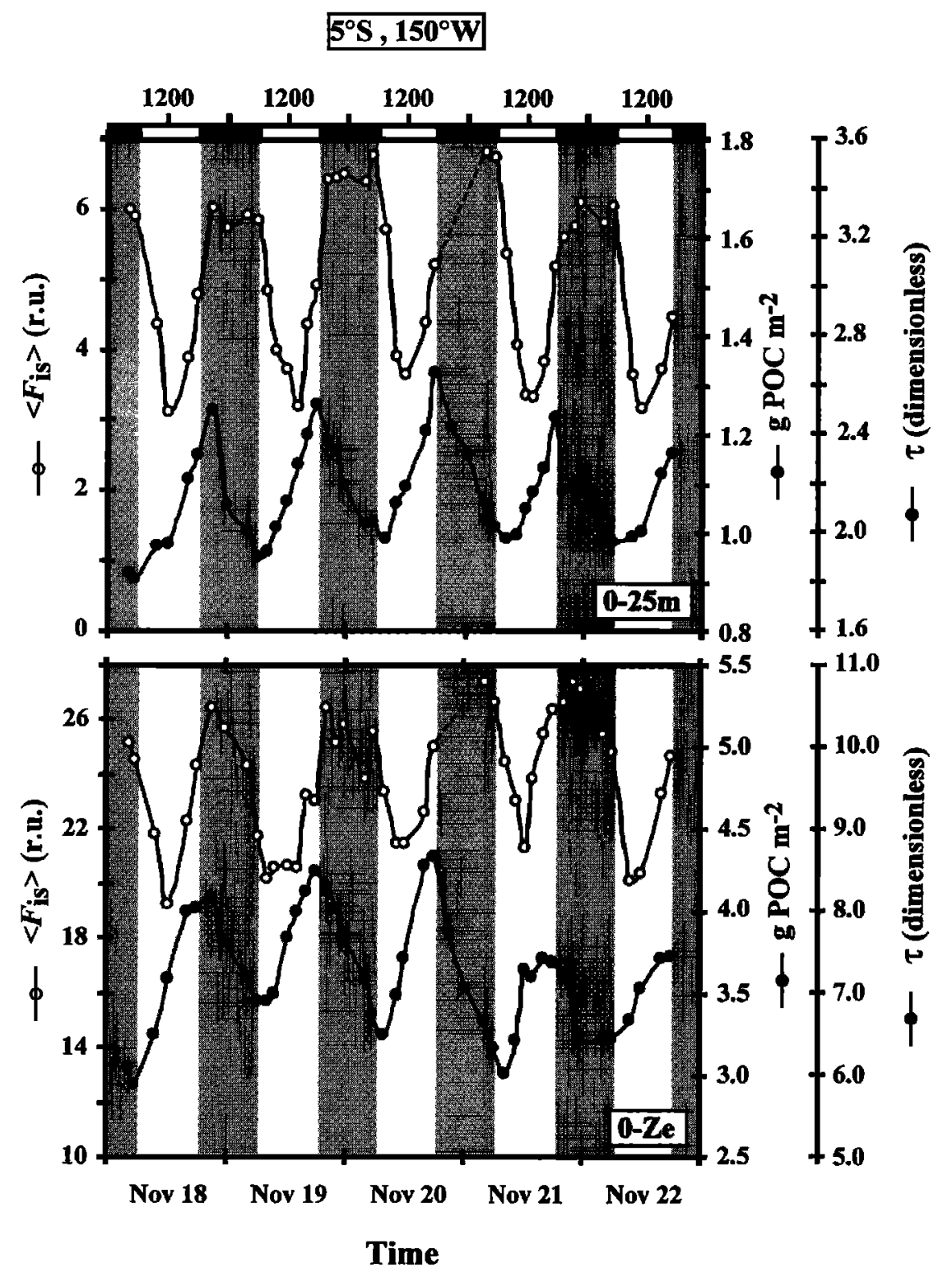

Figure 10. Temporal evolution of integrated fluorescence and integrated particle attenuation at $5^{\circ} \mathrm{S}$ for the $0-25 \mathrm{~m}$ layer or the euphotic layer, as indicated. The scale for particle attenuation is given in POC ( $\mathrm{mg} \mathrm{m}^{-2}$ ) and in optical thickness (dimensionless) equivalents. The scale for fluorescence is in relative units. 


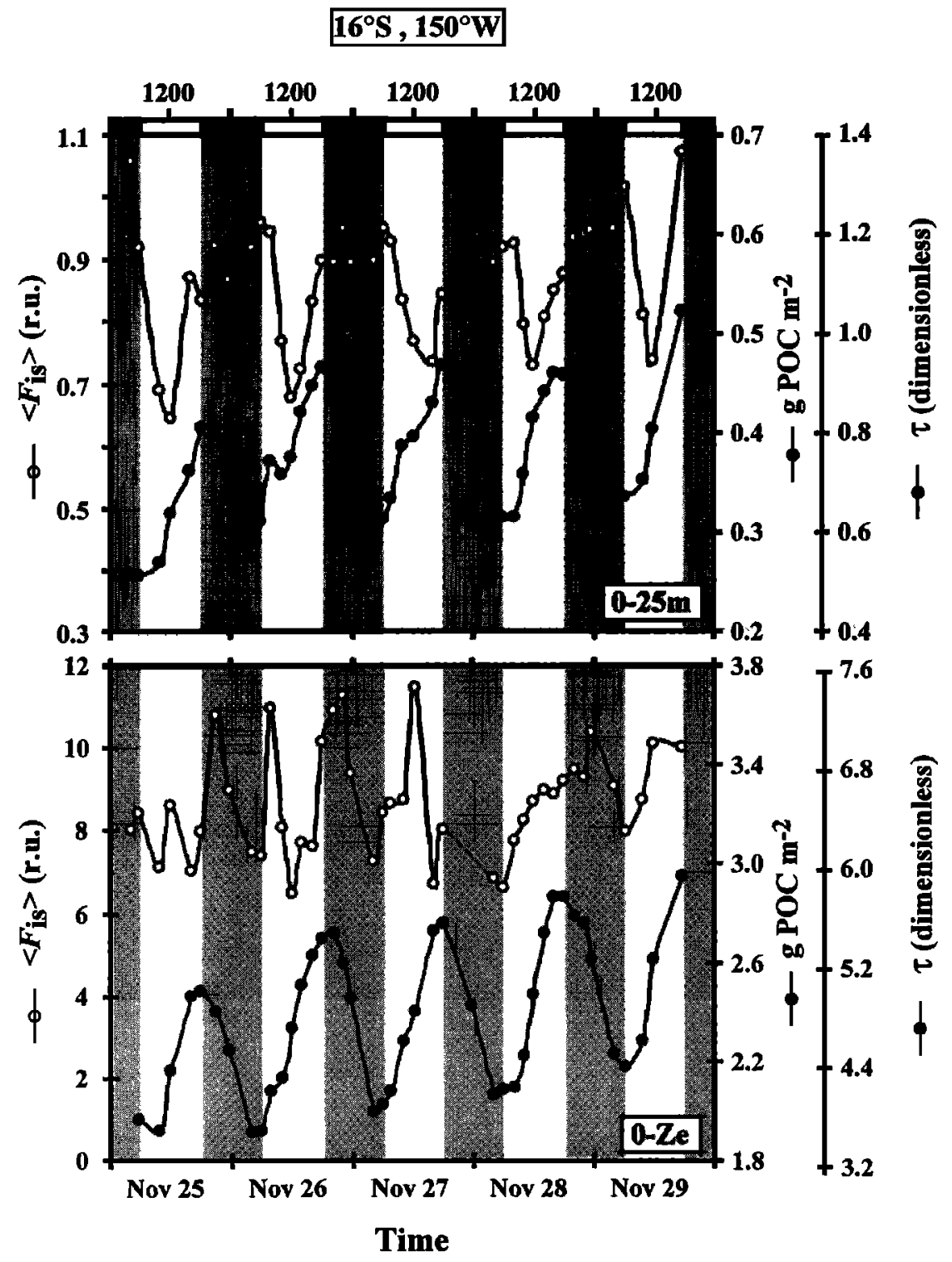

Figure 11. As in Figure 10, but for $16^{\circ} \mathrm{S}$.

where the integral corresponds to the areal POC content, denoted $\overline{\mathrm{POC}}\left(\mathrm{gC} \mathrm{m}^{-2}\right)$. As the adopted value for $c_{\mathrm{p}}^{\mathrm{c}}$ is 2 $\mathrm{m}^{2} \mathrm{gC}^{-1}$, the numerical relationship between $\tau_{\mathrm{p}}$ and $\overline{\mathrm{POC}}$ is therefore $\overline{\mathrm{POC}}=0.5 \tau_{\mathrm{p}}$.

Similarily, the vertical integration of $F_{\text {is }}$ would lead to an areal chlorophyll content ( $\left.\mathrm{g} \mathrm{chl} a \mathrm{~m}^{-2}\right)$ for a given layer, if chl $a$ and $F_{\text {is }}$ were tightly correlated. Because fluorescence is depressed around noon in surface layers, the correlation is not tight. Therefore column integrated chl $a$ values are meaningless when surface layers are considered in the integration.

In the upper layer as well as in the euphotic layer, $c_{\mathrm{p}}$ displays in both locations a clear diel cycle, with maxima around sunset (1800 LT) and minima around sunrise (0600 LT) (Figures 10 and 11). Such a regular $c_{\mathrm{p}}$ variation on a daily scale has been already documented for various oceanic situations like the north tropical Pacific [Siegel et al., 1989], the equatorial Pacific [DuRand and Olson, 1996; Walsh et al., 1995; Gardner et al., 1995], or the North Atlantic [Gardner et al., 1993, 1995]. Such variations are believed mainly to reflect the combined influences of (1) a change in particle content resulting from the balance between primary production and loss terms (grazing, sinking, aggregation, and nocturnal convection) [Walsh et al. 1995; Gardner et al., 1995] and (2) a daily "physiological" cycle affecting the specific attenuation of individual particles [e.g., Stramski and Reynolds, 1993]. This physiological cycle at the population level has been recently documented at the equator by $\mathrm{Du}$ Rand and Olson [1996] and at the same $5^{\circ} \mathrm{S}$ site by Vaulot and Marie [this issue]. Besides this general daily pattern, the temporal $c_{p}$ evolution presents some site-specific peculiarities.

Within the euphotic layer the $c_{\mathrm{p}}$ cycle is not fully reproducible over the 5 days at $5^{\circ} \mathrm{S}$. Indeed, from November 21 at noon (Figure 10), the timing as well as the magnitude of $c_{\mathrm{p}}$ variations are perturbed : both minima and maxima occur 
Table 2. Growth Rate Derived From $c_{\mathrm{p}}$ Daily Variations in Various Layers at $5^{\circ} \mathrm{S}$ and $16^{\circ} \mathrm{S}$

\begin{tabular}{|c|c|c|c|c|c|c|c|}
\hline & \multicolumn{3}{|c|}{$5^{\circ} \mathrm{S}$} & \multicolumn{4}{|c|}{$16^{\circ} \mathrm{S}$} \\
\hline & \multicolumn{2}{|c|}{ Growth Rate, $\left(\mathrm{d}^{-1}\right)$} & \multirow{2}{*}{ PAR $^{\mathbf{a}}$} & \multicolumn{3}{|c|}{ Growth Rate, $\left(\mathrm{d}^{-1}\right)$} & \multirow{2}{*}{ PAR $^{a}$} \\
\hline & $0-25 \mathrm{~m}$ & $0-Z e$ & & $0-25 \mathrm{~m}$ & $0-Z e$ & DCM Layer ${ }^{b}$ & \\
\hline Day 1 & 0.64 & 0.66 & 12.01 & 0.91 & 0.52 & 0.36 & 12.32 \\
\hline Day 2 & 0.56 & 0.41 & 11.75 & 0.88 & 0.70 & 0.42 & 12.88 \\
\hline Day 3 & 0.58 & 0.58 & 12.32 & 0.95 & 0.65 & 0.44 & 12.33 \\
\hline Day 4 & 0.45 & 0.42 & 12.66 & 0.85 & 0.66 & 0.34 & 11.63 \\
\hline Day 5 & 0.34 & 0.29 & 11.98 & 0.89 & 0.61 & 0.23 & 10.25 \\
\hline Mean & $0.51 \pm 0.11$ & $0.47 \pm 0.13$ & $12.14 \pm 0.35$ & $0.90 \pm 0.04$ & $0.63 \pm 0.07$ & $0.36 \pm 0.08$ & $11.88 \pm 1.02$ \\
\hline
\end{tabular}

a Photosynthetically available radiation (PAR) $[M J]$ is the daily irradiation at the sea surface for the photosynthetical range (400$700 \mathrm{~nm}$ ).

b The deep chlorophyll maximum (DCM) layer is the layer delimited by the 22.25 and 22.75 isopycnals, which on average, correspond to 110 and $160 \mathrm{~m}$, respectively.

7 hours before the expected time, and the amplitude of the variation is weaker than that recorded for the 3 preceding days. While the temporal shifts are not easily explainable (and in any case, not related to a change in PAR; see Table 2), the reduction of the mixed layer thickness (see Figure 9 and Plate 3) is responsible for the reduction in the integrated $c_{\mathrm{p}}$ signal. Moreover, Vaulot and Marie [this issue] have shown that the picophytoplankton concentration in surface layers was reduced (roughly by a factor of 1.5) from November 21 around noon, which may reinforce the previous suggestion of a hydrodynamic perturbation. If only the upper $(0-25 \mathrm{~m})$ layer is considered, the $c_{\mathrm{p}}$ cycle is regularly repeated.

At $16^{\circ} \mathrm{S}$ the well-featured $c_{\mathrm{p}}$ daily cycle is superimposed over a regular 5 day increase (Figure 11, see also Plate 4). This "long-term" trend corresponds to a net particle (or carbon) increase of $\sim 25 \%$ with respect to the initial stock. The cause of such a gain remains unknown. The 5 day observation, nevertheless, invalidates the postulate of steady state often stated for oligotrophic systems. The occurrence of "transient" states in typical oligotrophic environments has already been pointed out as resulting from storm events in the tropical North Pacific [DiTullio and Laws, 1991], but this was not the case during the present experiment.

The daily cycle in fluorescence in the $0-25 \mathrm{~m}$ layer, at $5^{\circ} \mathrm{S}$ as well as $16^{\circ} \mathrm{S}$, can be decomposed into two main phases: minima are restricted to a narrow period around noon, while maxima extend nearly all the night long. The range of variation in $F_{\text {is }}$ is greater at $5^{\circ} \mathrm{S}$ (roughly by a factor 2 ) than at $16^{\circ} \mathrm{S}$ (factor 1.4). These daily patterns in $F_{\text {is }}$ are almost identical to what is reported for the diel variation of fluorescence per cell in surface populations of Prochlorococcus and, to a lesser extent, Synechococcus [Vaulot and Marie, this issue]. As the red fluorescence per cell of picoeucaryotes does not display any significant variation [Vaulot and Marie, this issue], prokaryotic cells would be the main drivers of daily $F_{1 s}$ variations within the top $25 \mathrm{~m}$ layer. The pronounced decrease in fluorescence during daytime is probably due to energy-dependent $(\Delta p \mathrm{H})$ nonphotochemical quenching [see Krause and Weis, 1991] together with a possible influence of nonphotochemical quenching by nonphotosynthetic pigments. Zeaxanthin, a nonphotosynthetic pigment present in Synechococcus [Kana et al., 1988] and in Prochlorococcus [Cailliau et al., 1996], is seemingly the candidate for the nonphotochemical quenching in these prokaryotic cells. However, this pigment, contrary to the pigments of the xantophyll cycle in picoeucaryotes (diadinoxanthin + diatoxanthin), does not exhibit any daily cycle (H. Claustre, unpublished results, 1997). Therefore, nonphotochemical quenching by photoprotective pigments is certainly a process of minor importance in the fluorescence inhibition recorded at noon, compared to energy-dependent nonphotochemical quenching.

Over the entire euphotic layer at $5^{\circ} \mathrm{S}$ a clear daily cycle in $F_{\text {is }}$ is maintained with minima around noon and maxima just after sunset. Nevertheless, in contrast to what happens in the surface layer, these maximal values do not extend all the night long. At $16^{\circ} \mathrm{S}$ the temporal evolution of $F_{\text {is }}$ within the euphotic layer is rather erratic (Figure 11), as a result of an artifact due to the depth of integration. Indeed, integration performed over the 0-Ze layer includes a varying portion of the DCM, which fluctuates according to the density field oscillation (see above and Figure 9 and Plate 4). To analyze specifically the algal biomass and its evolution within the DCM, the integration was performed between the depths corresponding to $\sigma=24.25$ and $\sigma=24.75$ which unambiguously encompass the whole DCM. In this deep layer, $c_{\mathrm{p}}$ still presents a daily cycle (Figure 12 ), roughly in phase with that observed in the above layers and the 5 day trend. When integrated over the whole DCM, fluorescence experiences a distinct daily cycle in phase with the $c_{\mathrm{p}}$ evolution. At this level the fluorescence increase during the first part of the day cannot result from photoadaptation processes like an increase in the internal concentration of chlorophyll $a$ or in the fluorescence yield (such processes are thought to occur at night). Therefore such periodic changes would reflect a net increase in the DCM algal content in daytime as is simultaneously attested by $F_{\text {is }}$ and $c_{\mathrm{p}}$. The boundaries of the DCM layer roughly correspond to depths where PAR is reduced to $2 \%$ and $0.2 \%$ of its surface value. The observation 
$16^{\circ} \mathrm{S}, 150^{\circ} \mathrm{W}$

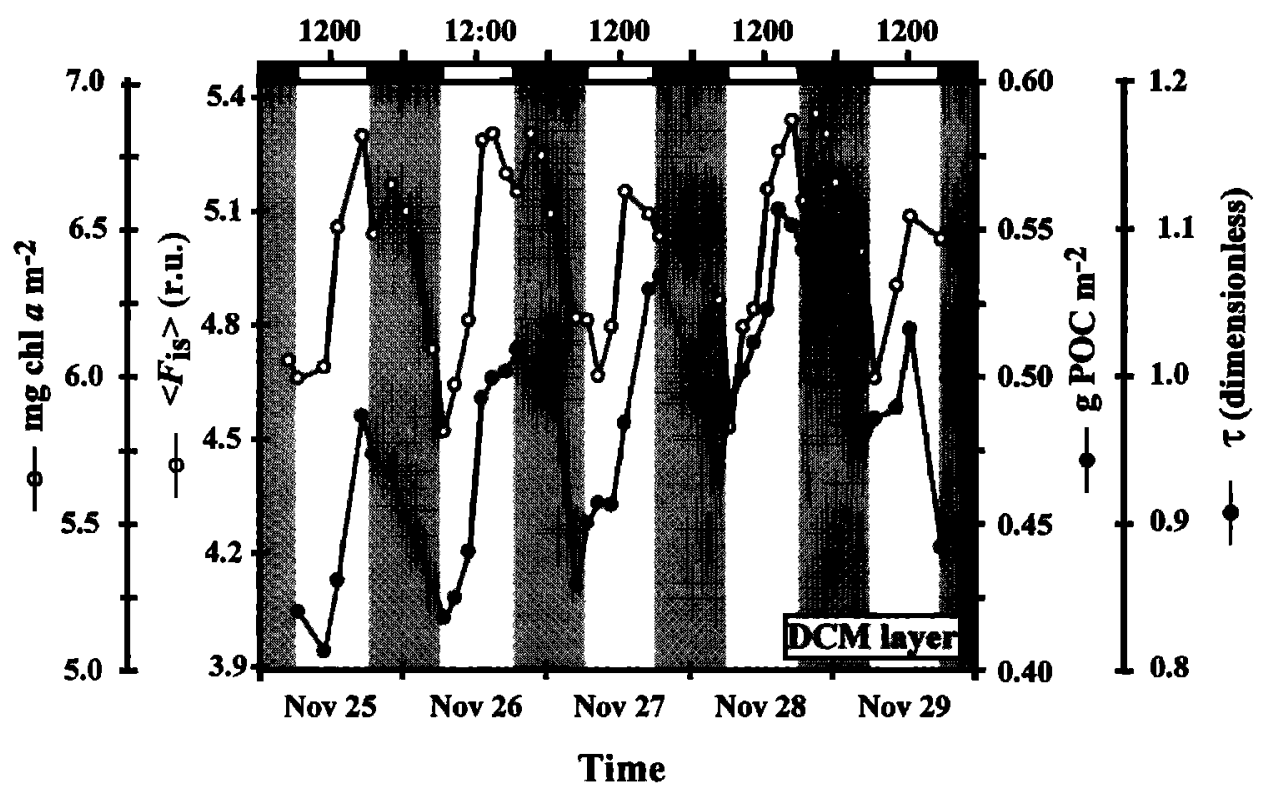

Figure 12. As in Figure 10, but for the deep chlorophyll maximun (DCM) layer at $16^{\circ} \mathrm{S}$. The scale for fluorescence is also given in chl $a\left(\mathrm{mg} \mathrm{m}^{-2}\right)$ equivalents because this layer is not concerned by fluorescence depression at noon (see text).

of a daily cycle at this level (and even down to the 25.25 isopycnal, i.e., at $210 \mathrm{~m}$ where PAR is reduced to $0.04 \%$ of its surface value; data not shown) does not corroborate the findings of Siegel et al. [1989] in the North Pacific gyre $\left(33^{\circ} \mathrm{N}, 144^{\circ} \mathrm{W}\right)$, who limited to the euphotic depth the possibility of observing any diurnal cycle in $c_{\mathrm{p}}$. However, in agreement with the statement by Siegel et al. [1989], $c_{\mathrm{p}}$ did not display any diel cycle within a DCM (at $130 \mathrm{~m}$ ) in oligotrophic eastern mediterranean waters (H. Claustre, unpublished results, 1997). At $16^{\circ} \mathrm{S}$ the DCM algal biomass was dominated by picoeucaryotes (see Figure 7), with a concentration $\sim 10$ times higher than that in the mediterranean site (D. Vaulot, unpublished results, 1997). Such a deep daily "activity" and light response at the DCM level are perhaps typical of picoeucaryotes. In the future, efforts have to be directed toward the study of the biomass and physiology (light and nutrient requirements) of this poorly known algal group in order to better understand the role, in ultraoligotrophic systems, of the DCM in the control of biogeochemical cycles.

3.4.3. Cyclic growth rates. Because the daily increase in $c_{\mathrm{p}}$ corresponds to a net accumulation of particulate material [Siegel et al., 1989; Walsh et al., 1995; Marra, 1997], a $c_{\mathrm{p}}$-based net growth rate for this material $\left(\mu, \mathrm{d}^{-1}\right)$ can be derived through the relation:

$$
\mu=2 \ln \left(c_{\mathrm{p}}^{\max } / c_{\mathrm{p}}^{\min }\right)
$$

where $c_{\mathrm{p}}^{\max }$ and $c_{\mathrm{p}}^{\min }$ represent the maximum and minimum values in $c_{\mathrm{p}}$ over a 24 hour cycle (0000-0000 LT) and the factor 2 stands for the increase in $c_{\mathrm{p}}$ being restricted to a 12 hour period (roughly from 0600 to $1800 \mathrm{LT}$ ). This growth rate cannot strictly be attributed to the sole algal compartment and photosynthesis process, because algae form only a fraction of the particulate material (Table 1). In addition, it should be stressed that scattering cross sections of phytoplankton may vary over the diel cycle [e.g., Stramski and Reynolds, 1993]. If a population of very small unicellular organisms undergoes cell division in a synchronous way, the scattering coefficient (attenuation) is depressed (by 20\%) when the cell number is muliplied by 2 and as long as the total volume has not yet increased. The decrease in $c_{\mathrm{p}}$ observed at nighttime actually coincides with the algal cell division [Vaulot and Marie, this issue]; the wider amplitude of the decrease, however, cannot be explained by the above optical effect.

At $5^{\circ} \mathrm{S}$ the mean value in the $0-25 \mathrm{~m}$ layer $\left(0.51 \mathrm{~d}^{-1}\right)$ is not statistically different from that in the euphotic zone $(0.47$ $\mathrm{d}^{-1}$ ) (Table 1), likely as a result of efficient mixing conditions. Over the 5 days of observation the range of variations within the euphotic zone $\left(0.29-0.66 \mathrm{~d}^{-1}\right)$ is similar to the range (0.10-0.60 d $\left.\mathrm{d}^{-1}\right)$ reported by Walsh et al. [1995] at the equatorial divergence. At this station an average Prochlorococcus division rate of $0.66 \mathrm{~d}^{-1}$ (i.e., very close to one division per day) within the euphotic zone was derived from the DNA measurements of Vaulot and Marie [this issue]. Such a division rate actually is equivalent to a gross growth rate. By assuming that Synechococcus and picoeucaryotes have the same gross growth rate as Prochlorococcus the loss rate during the day can be tentatively estimated to $0.19 \mathrm{~d}^{-1}(0.66$ minus 0.47). The loss rate during the night is equivalent to $\mu\left(0.47 \mathrm{~d}^{-1}\right)$, i.e., more than twice its value at daytime 
$\left(0.19 \mathrm{~d}^{-1}\right)$, since net $c_{\mathrm{p}}$ accumulation over a 24 hour period is roughly equal to 0 . This would mean that grazing is more effective during the night (see analysis by André et al. [this issue]) and/or that other processes (e.g., aggregation, dilution by mixing) [Gardner et al., 1995] account for the $c_{\mathrm{p}}$ reduction during the night.

The paradigm according to which central regions of the ocean would be vast biological deserts, has been challenged by various experimental results. For instance, Laws et al. [1987] showed that in oligotrophic situations the phytoplankton growth rate is more vigorous than previously thought, and could reach $\sim 1.5 \mathrm{~d}^{-1}$ in surface layers. The present estimates at $16^{\circ} \mathrm{S}$ (Table 2) in the $0-25 \mathrm{~m}$ layer $\left(0.91 \mathrm{~d}^{-1}\right)$ or in the euphotic zone $\left(0.63 \mathrm{~d}^{-1}\right)$ confirm the rapid turnover time of particulate matter in such an impoverished environment. It must be recalled that only $20 \%$ of the particle stock at $16^{\circ} \mathrm{S}$ is attributable to the vegetal pool in the euphotic zone (Table 1). Therefore, if it assumed that the algal population is responsible for the daily $c_{\mathrm{p}}$ increase, its growth rate would be $\sim 2.1 \mathrm{~d}^{-1}$. This uncomfortably high value would suggest that other compartments (heterotrophic bacteria, in particular) are involved in the cyclic growth depicted by $c_{\mathrm{p}}$. The high growth rates recorded within the DCM $\left(0.36 \mathrm{~d}^{-1}\right.$, when PAR $=0.3 \%$ of its surface value) support this explanation, even if picoeucayotes, dominant at this level (see Table 1 and Figure 7), can, perhaps, keep an exceptional ability to cope with an extremely low light (but nutrient-rich) environment. At the DCM level (Figure 12), as well as at the surface layer (Figure 11), the 5 day $c_{\mathrm{p}}$ increase is not associated with a parallel increase in $F_{\text {is. }}$. In other words, the long-term particle accumulation at $16^{\circ} \mathrm{S}$ would affect the nonvegetal stock rather than the vegetal one, which essentially remains constant.

Growth rate calculations based on daily $c_{\mathrm{p}}$ changes are robust because they are independent from any conversion factor. Net community production rates can tentatively be derived as soon as the factor needed to convert $c_{\mathrm{p}}$ into POC (and therefore $\Delta c_{p}$ into primary production) is known and do not vary over the daily cycle [Cullen et al., 1992]. By using the conversion factor previously determined (Figure 2), average $c_{\mathrm{p}}$-based primary production rates of $0.85 \mathrm{~g} \mathrm{C} \mathrm{m}^{-2} \mathrm{~d}^{-1}$ $\pm 0.27\left(\right.$ at $5^{\circ} \mathrm{S}$ ) and $0.74 \mathrm{~g} \mathrm{C} \mathrm{m}^{-2} \mathrm{~d}^{-1} \pm 0.10\left(\right.$ at $\left.16^{\circ} \mathrm{S}\right)$ are derived. These rates compare quite well with in situ ${ }^{14} \mathrm{C}$ based estimations corresponding to $0.65 \mathrm{~g} \mathrm{C} \mathrm{m}^{-2} \mathrm{~d}^{-1} \pm 0.22$ (at $5^{\circ} \mathrm{S}$ ) and to $0.66 \mathrm{gC} \mathrm{m}^{-2} \mathrm{~d}^{-1} \pm 0.14$ (at $16^{\circ} \mathrm{S}$ ) (P. Conan and P. Raimbault, unpublished data, 1997). In the past, comparison of optically determined production with carbon uptake determination has, nevertheless, led to some contradictory results. While Siegel et al. [1989] found that optically determined production exceeds, by a factor of 1.5 , the measured ${ }^{14} \mathrm{C}$ primary production (north tropical Pacific), $\mathrm{Cul}$ len et al. [1992] reported a general agreement between both techniques (equatorial Pacific). Finally, in the same area, Walsh et al. [1995] found that optically determined production was 3 times lower than ${ }^{14} \mathrm{C}$-based estimates. The conversion factors of 180 and $257 \mathrm{mgC} \mathrm{m}^{-3}$ per m $\mathrm{m}^{-1}$, used by Walsh et al. [1995] for two cruises in the equatorial Pacific, were determined on the basis of a POC/PMC ratio of 0.4, a value actually established for the North Atlantic Bloom Experiment. As coccolithophorids are particularly abundant in the North Atlantic [Holligan et al., 1983; Jickells et al., 1996], it is likely that the value of 0.4, typical for waters with high calcite content, does not apply in equatorial $\mathrm{Pa}$ cific waters. Thus there might be much closer agreement between the two techniques than they concluded.

\section{Conclusions}

Fluorescence and attenuation are only bulk indices of particle abundance (total or vegetal) with, nevertheless, the advantage of being measurable in a continuous way. The present study stresses that when such continuous measurements are combined with detailed analyses of the particle composition (namely, flow cytometry enumeration and HPLC pigment determination), very useful information can be gathered which is helpful in describing and understanding the role of various biological stocks in particulate matter cycling. Therefore, even if transmissiometers or fluorometers are now largely used as part of towed or moored "selfsufficient" platforms, it remains essential to pursue parallel measurements aiming at calibrating and decomposing the signals into their various contributors. To our knowledge, only Pacific equatorial waters [Walsh et al., 1995; Chung et al., 1996, 1998; DuRand and Olson, 1996; this study] and the South Pacific gyre (this study) have been investigated in this respect.

The $c_{\mathrm{p}}$ "budget" performed in the first part of this study depends, however, on specific assumptions about the size structure of the algal populations; these assumptions also influence the estimate of the detrital pool, which is obtained by difference. As pointed out, the budget is heavily dependent upon the size adopted for the picoeukaryote compartment. This population is more diverse and presumably much less documented than the Prochlorococcus and Synechococcus populations. There is therefore an urgent need to determine at sea the size of the various picoplanktonic assemblages. In spite of these inevitable uncertainties the detrital pool, nevertheless, appears to be a major contributor to the particulate stock in the very oligotrophic situation of the South Pacific gyre and is still an important contributor in quasimesotrophic regimes such as those encountered at $5^{\circ} \mathrm{S}$ and at the equator. Therefore quantitative and qualitative information on this unknown pool is still needed not only to better interpret transmissiometry signals but also to understand its influence on biogeochemical cycles.

Finally, our results clearly point out two main sources of variation in fluorescence and attenuation. The first source of variation, evident at large scales, is related to changes in particle abundance induced by variations in hydrodynamics and associated trophic regimes. The second source of variability is essentially local and is related to the specific circadian rhythms of biological and physiological processes. In particular, our results show that the daily accumulation in particles can account for up to $50 \%$ of the stock present at sunrise and that the fluorescence at noon can be depressed by a factor of 2 during the increasing phase of attenuation. In oligotrophic 
systems associated with gyres such diurnal variations can be of the same range as those expected on a seasonal or basinwide scale. Therefore great care should be taken when using transmissiometry or fluorescence databases, which are becoming widely exploited for regional, or even global, generalizations and studies.

Acknowledgments. This work is a contribution to the French JGOFS programs "EPOPE" and "PROSOPE" and to the GDR 869 funded by CNRS-INSU. D.V. and D.M. were partially funded by the MAST MEDEA program (CT 95/0016). We thank Y. Dandonneau as coordinator of the EPOPE program, and B. Coste as chief scientist of the OLIPAC cruise. The help of C. Boumot was highly appreciated during field work. ADCP, nutrient, primary production, and euphotic zone depth data were kindly provided by C. Menkes, P. Raimbault, P. Conan, and S. Maritorena, respectively. B. Gentili is duly acknowledged for a careful preparation of the camera-ready manuscript. The authors wish to thank two unknown referees for helpful criticisms.

\section{References}

Abbott, M. R., K. H. Brink, C. R. Booth, D. Blasco, L. A. Codispoti, P. P. Niller, and S. R. Ramp, Observations of phytoplankton and nutrients from a Lagrangian drifter off northem California, J. Geophys. Res., 95, 9393- 9409, 1990.

André, J.-M., C. Navarette, J. Blanchot, and M.-H. Radenac, Picophytoplankton dynamics in the equatorial Pacific: Growth and grazing rates from cytometric counts, J. Geophys. Res., this issue.

Baker, E. T., and J. W. Lavelle, The effect of particle size on the light attenuation coefficient of natural suspensions, J. Geophys. Res., 89, 8197-8203, 1984.

Bricaud, A., A. Morel, and L. Prieur, Absorption by dissolved organic matter of the sea (yellow substance) in the UV and visible domains, Limnol. Oceanogr, 26, 43-53, 1981.

Cailliau, C., Les pigments comme biomarqueurs spécifiques des stocks et flux de matıère autotrophe en milieu marin: Application à l'Océan austral et l'Océan Pacifique equatorial, Ph.D. thesis, 209 pp., Université Pierre el Marie Curie, Paris, 1996.

Cailliau, C., H. Claustre, F. Vidussi, D. Marie, and D. Vaulot, Carbon biomass, and gross growth rates as estimated from ${ }^{14} \mathrm{C}$ pigment labeling, during photoacclimation in Prochlorococcus CCMP 1378, Mar. Ecol. Prog. Ser., 145, 209-221, 1996.

Campbell, L., and D. Vaulot, Photosynthetic picoplankton community structure in the subtropical North Pacific Ocean near Hawaii (station ALOHA), Deep Sea Res., Part I, 40, 2043-2060, 1993.

Campbell, L., H. A. Nolla, and D. Vaulot, The importance of Prochlorococcus to community structure in the central North Pacific Ocean, Limnol. Oceanogr., 39, 954-961, 1994.

Chung, S. P., W. D. Gardner, M. J. Richardson, I. D. Walsh, and M. R. Landry, Beam attenuation and micro- organisms: Spatial and temporal variations in small particles along $140^{\circ} \mathrm{W}$ during the 1992 JGOFS EqPac transects, Deep Sea Res., Part II, 43, 1205-1226, 1996.

Chung, S. P. , W. D. Gardner, M. R. Landry, M. J. Richardson and I. D. Walsh, Beam attenuation by micro- organisms in the equatorial Pacific, J. Geophys Res., 103, 12,669-12,681, 1998.

Claustre, H., and J.-C. Marty, Specific phytoplankton biomasses and their relation to primary production in the tropical North Atlantic, Deep Sea Res., Part l, 42, 1475-1493, 1995.

Cullen, J. J., The deep chlorophyll maximum: Comparing vertical profiles of chlorophyll a, Can. J. Fish. Aquat. Sci., 39, 791-803, 1982.

Cullen, J. J., M. R. Lewis, C. O. Davis, and R. T. Barber, Photosynthetic characteristics and estimated growth rates indicate grazing is the proximate control of primary production in the equatorial Pacific, J. Geophys. Res., 97, 639-654, 1992.
Dickey, T., J. Marra, T. Granata, C. Langdon, M. Hamilton, J. Wiggert, D. Siegel, and A. Bratkovich, Concurrent high-resolution bio-optical and physical time series observations in the Sargasso Sea during the spring of 1987, J. Geophys. Res., 96, 8643-8663, 1991.

DiTullio, G. R., and E. A. Laws, Impact of an atmospheric-oceanic disturbance on phytoplankton community dynamics in the North Pacific central gyre, Deep Sea Res., Part A, 38, 1305-1329, 1991.

DuRand, M. D., and R. J. Olson, Contributions of phytoplankton light scattering and cell concentration changes to diel variations in beam attenuation in the equatorial Pacific from flow cytometric measurements of pico-, ultra- and nanoplankton. Deep Sea Res., Part II, 43, 891-906, 1996.

Falkowski, P. G., Light-shade adaptation in marine phytoplankton, in Primary Productivity in the Sea, edited by P. G. Falkowski, pp. 99-119, Plenum, New York, 1980.

Gardner, W. D., M. J. Richardson, I. D. Walsh and B. L. Berglund, In-situ optical sensing of particles for determination of oceanic processes, Oceanography, 3, 11-17, 1990.

Gardner, W. D., I. D. Walsh, and M. J. Richardson, Biophysical forcing of particle production and distribution during a spring bloom in the North Atlantic, Deep Sea Res., Part II, 40, 171$195,1993$.

Gardner, W. D., S. P. Chung, M. J. Richardson, and I. D. Walsh, The oceanic mixed-layer pump, Deep Sea Res., Part II, 42, 757-775, 1995.

Holligan, P. M., M. Viollier, D. S. Harbour, P. Camus, and M. Champagne-Philippe, Satellite and ship studies of coccolithophore production along a continental shelf edge, Nature, 304 , 339-342, 1983.

Jickells, T. D., P. P. Newton, P. King, R. S. Lampitt, and C. Boutle, A comparison of sediment trap records of particulate fluxes from $19^{\circ}$ to $48^{\circ} \mathrm{N}$ in the northeast Atlantic and their relation to surface water productivity. Deep Sea Res., Part II, 43, 971-986, 1996.

Kana, T. M., P. M. Glibert, R. Goericke and N. A. Welschmeyer, Zeaxanthin and $\beta$-caroten in Synechococcus WH7803 respond differentely to irradiance, Limnol. Oceanogr., 33, 1623-1627, 1988.

Kutchen, J. C., and J. R. V. Zaneveld, On the noncorrelation of the vertical structure of light scattering and chlorophyll $a$ in case I waters, J. Geophys. Res., 95, 20,237-20,246, 1990.

Krause, G. H., and E. Weis, Chlorophyll fluorescence and photosynthesis: The basics, Annu. Rev. Plant Physio. Plant Mol. Biol., 42, 313-349, 1991,

Laws, E. A., G. R. DiTullio, and D. G. Redalje, High phytoplankton growth and primary production rates in the North Pacific subtropical gyre, Limnol. Oceanogr., 32, 905-918, 1987.

Loisel, H., and A. Morel, Light scattering and chlorophyll concentration in case I waters : a re-examination. Limnol. Oceanogr., $43,847-858,1998$.

Lorenzen, C. J., A method for the continuous measurement of in vivo chlorophyll concentration, Deep Sea Res., 13, 223-227, 1966.

Marie, D., F. Partensky, S. Jacquet, and D. Vaulot, Enumeration and cell cycle analysis of natural populations of marine picoplankton by flow cytometry using the nucleic acid stain SYBR Green I, Appl. Environ. Microbiol., 63, 186-193, 1997.

Marra, J., Analysis of diel variability in chlorophyll fluorescence, J. Mar. Res., 55, 767-784, 1997.

Morel, A., Diffusion de la lumière par les eaux de mer: Résultats expérimentaux et approche théorique, in Optics of the Sea, AGARD Lecture Ser., 61, 3.1.1-3.1.76, 1973.

Morel, A., and Y.-H. Ahn, Optics of heterotrophic nanoflagellates and ciliates: A tentative assesment of their scattering role in oceanic waters compared to those of bacterial and algal cells, J. Mar. Res., 49, 177-202, 1991.

Morel, A., Y.-H. Ahn, F. Partensky, D. Vaulot, and H. Claustre, Prochlorococcus and Synechococcus: A comparative study of their optical properties in relation to their size and pigmentation, J. Mar. Res., 51, 617-649, 1993. 
Murray, J. W., R. T. Barber, M. R. Roman, M. P. Bacon, and R. A. Feely, Physical and biological controls on carbon cycling in the equatorial Pacific, Science, 266, 58-65, 1994.

Neale, P. J., and P. J. Richarson, Photoinhibition and the diurnal variation of phytoplankton photosynthesis, I, Development of a photosynthesis-irradiance model from studies of in situ responses, J. Plankton Res., 9, 167- 193, 1987.

Neale, P. J., J. J. Cullen and C. M. Yentsch, Bio-optical inferences from chlorophyll $a$ fluorescence: What kind of fluorescence is measured in flow cytometry ?, Limnol. Oceanogr., 34, 1739 . $1748,1989$.

Pak, H., D. A. Kiefer, and J. C. Kitchen, Meridional variations in the concentration of chlorophyll and microparticles in the North Pacific Ocean, Deep Sea Res., Part A, 35, 1151-1171, 1988.

Peña, M. A., M. R. Lewis, and W. G. Harrison, Particulate organic matter and chlorophyll in the surface layer of the equatorial $\mathrm{Pa}$ cific Ocean along $135^{\circ}$ W, Mar. Ecol. Prog. Ser., 72, 179-188, 1991.

Platt, T. and S. Sathyendranath, Oceanic primary production: Estimation by remote sensing at local and regional scales, Science, 241, 1613-1620, 1988.

Siegel, D. A., T. D. Dickey, L. Washbum, M. K. Hamilton, and B. G. Mitchell, Optical determination of particulate abundance and production variations in the oligotrophic ocean, Deep Sea Res., Part A, 36, 211-222, 1989.

Simon, N., R. G. Barlow, D. Marie, F. Partensky, and D. Vaulot, Characterization of oceanic photosynthetic picoeukaryotes by flow cytometry, J. Phycol., 30, 922-935, 1994.

Spinrad, R. W., J. R. V. Zaneveld, and J. C. Kitchen, A study of the optical characteristics of the suspended particles in the benthic boundary layer of the Scotian Rise, J. Geophys. Res., 88, 7641$7645,1983$.

Stoens, A., et al., The coupled physical new production system in the equatorial Pacific during the 1992-1995 El Niño, J. Geophys. Res., this issue.

Stramska, M., and T. D. Dickey, Variability of bio-optical properties of the upper ocean associated with diel cycles in phytoplankton populations, J. Geophys. Res., 97, 17,873-17,887, 1992.

Stramski, D., Gas microbubbles: An assesment of their significance to light scattering in quiescent seas, Proc. SPIE Int. Soc. Opt. Eng., 2258, 704-710, 1994.

Stramski, D., and D. Kiefer, Light scattering by microorganism in the open ocean, Prog. Oceanogr., 28, 343-383, 1991

Stramski, D., and R. A. Reynolds, Diel variations in the optical properties of a marine diatom, Limnol. Oceanogr., 38, 13471364, 1993.

Strass, V., On the calibration of large-scale fluorimetric chlorophyll measurments from towed undulating vehicles, Deep Sea Res., Part A, 37, 525-540, 1990.

Van de Hulst, H. C., Light Scattering by Small Particles, Wiley, New York, 1957.

Vaulot, D., and D. Marie, Diel variability of photsynthetic picoplankton in the equatorial pacific, J. Geophys. Res., this issue.

Vidussi, F., H. Claustre, J. Bustillos-Guzmán, C. Cailliau, and J.-C. Marty, Rapid HPLC method for determination of phytoplankton chemotaxinomic pigments: Separation of chlorophyll $a$ from divinyl-chlorophyll $a$ and zeaxanthin from lutein, J. Plankton Res., 18, 2377-2382, 1996.

Walsh, I. D., S. P. Chung, M. J. Richardson, and W. D. Gardner, The diel cycle in the integrated particle load in the equatorial Pacific: A comparison with primary production, Deep Sea Res., Part II, 42, 465-477, 1995.

Wyrtki, K., and B. Kilonsky, Mean water and current structure during the Hawaii-to-Tahiti shuttle experiment, J. Phys. Oceanogr., 14, 242-254, 1984.

M. Babin, C. Cailliau, H. Claustre, J.-C. Marty, A. Morel and D. Tailliez, Observatoire Océanologique de Villefranche, Laboratoire de Physique et Chimie Marines, Université Pierre et Marie Curie and Centre National de la Recherche Scientifique / Institut National des Sciences de l'Univers, B.P. 08, 06238, Villefranchesur-mer cedex, France. (claustre@obs-vlfr.fr)

D. Marie and D. Vaulot, Station Biologique de Roscoff, Université Pierre et Marie Curie and Centre National de la Recherche Scientifique / Institut National des Sciences de l'Univers, BP 74, 29682, Roscoff cedex, France.

(Received December 12, 1997; revised April 1, 1998; accepted April 22, 1998.) 